BASE FLOW OF STREAMS ON LONG ISLAND, NEW YORK

By Richard J. Reynolds

U.S. GEOLOGICAL SURVEY

Water-Resources Investigations 81-48

Prepared in cooperation with the

NASSAU COUNTY DEPARTMENT OF PUBLIC WORKS AND

SUFFOLK COUNTY DEPARTMENT OF HEALTH SERVICES

Syosset, New York 
UNITED STATES DEPARTMENT OF THE INTERIOR

JAMES G. WATT, Secretary

GEOLOGICAL SURVEY

Dallas L. Peck, Director

For additional information write to:

U.S. Geological Survey

5 Aerial Way

Syosset, New York 11791 


\section{CONTENTS}

Abstract

Introduction _._____ 1

Purpose and scope _._. 4

Regional hydrogeology _..

Method of hydrograph separation _ 8

Long Island base-flow data _._.

Hydrograph separation _._._.

Relationship of base flow to flow duration _._. 12

Summary _- _ _ _

References cited _._._._____ 15

\section{ILLUSTRATIONS}

Figure 1. Map of Long Island showing location of streans and gaging stations used to obtain base-flow data_...................

2. Generalized cross section of Long Island showing major

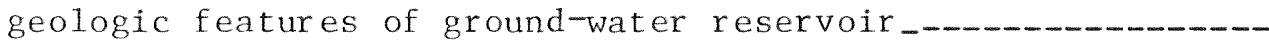

3. Diagram showing generalized equipotential and flow lines along a typical north-south cross section in ground-water system of central Long Island under natural conditions_._...-.

4. Map showing ground-water flow net in vicinity of East Meadow Brook

5. Semilogarithmic plot of hydrograph for East Meadow Brook at Freeport, showing separation of discharge components...-.-

6. Segment of daily mean discharge hydrograph for Car11s River showing base-flow separation_...

7. Monthly mean base-flow hydrograph for Connetquot River, Car11s River, and Massapequa Creek for water years 1960-75-

8. Graph showing relationship between annual mean base flow and discharge at 55-percent duration for Long Island streams

\section{TABLES}

Table 1. Annual mean base flow for 19 continuously gaged streams

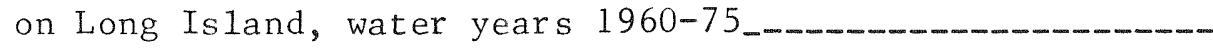

2. Monthly mean base flow for 19 continuously gaged streams on Long Island, water years 1960-75 


\section{Factors for Converting Inch-Pound Units to International Systems (SI) Units, and Abbreviations of Units}

Multiply Inch-pound unit

foot ( $\mathrm{ft}$ )
mile (mi)
cubic feet per second
$\left(\mathrm{ft}^{3} / \mathrm{s}\right)$

by

Length

$$
\begin{array}{ll}
.3048 & \text { meter }(\mathrm{m}) \\
1.609 & \text { kilometer }(\mathrm{km})
\end{array}
$$

Flow

28.32
To obtain SI unit

cubic meters per second $\left(\mathrm{m}^{3} / \mathrm{s}\right)$

1iters per second (L/S)

\section{DEFINITIONS}

NGVD, National Geodetic Vertical Datum of 1929. A geodetic datum derived from a general adjustment of the first-order level nets of both the United States and Canada, formerly called "mean sea level." NGVD of 1929 is referred to as "sea level" in this report. 


\title{
BASE FLOW OF STREAMS ON LONG ISLAND, NEW YORK
}

\author{
By
}

\author{
Richard J. Reynolds
}

\begin{abstract}
On Long Island, ground water under nonurbanized conditions constitutes 90 to 95 percent of the total stream discharge. Base-flow data from 19 continuously gaged streams are presented as monthly mean and annual mean discharge in tables for water years 1960-75, which includes the 1962-66 drought. The data were derived by hydrograph-separation procedures that isolate daily mean base flow from daily mean discharge. A close empirical relationship between annual mean base flow and stream discharge at the 55-percent duration point facilitates estimation of average base flow and can be used in place of the more time-consuming hydrograph-separation technique.

These data are needed in calibration of computer models that will be used to predict the effects of hydrologic stresses, such as sewering, on Long Island's ground-water system.
\end{abstract}

\section{INTRODUCTION}

The streams of Long Island, N.Y., can be characterized as relatively shallow and straight, with few or no tributaries and sustained predominantly by ground water. The ground-water contribution, also termed base flow, has been estimated to constitute 90 to 95 percent of the total discharge of each stream under nonurbanized conditions (Pluhowski and Kantrowitz, 1964); the remainder consists of intermittent direct runoff from precipitation. Because the water-table altitude in the vicinity of any of these streams determines the amount of ground-water flow to that stream, any major lowering of ground-water levels on the island will correspondingly reduce stream base flow.

The lowering of ground-water levels may be caused by a long-term reduction in recharge to the ground-water body. This reduction can be the result of a drought or large-scale sanitary and storm sewering.

Recent investigations (Pluhowski and Spine11o, 1978) indicate that a general lowering of ground-water levels in Sewer District 2 in Nassau County (fig. 1) due to large-scale sanitary and storm sewering has reduced the base flow of East Meadow Brook by 60 percent since 1953. Approximately 75 percent of this base-flow "loss" is caused by the sanitary sewer networks, which intercept and route to tidewater the wastewater that would normally recharge the ground-water body. The remaining 25 percent of base-flow "loss" is attributed to reduced infiltration of precipitation as a result of large-scale paving of open land and redirection of runoff to streams through storm sewers. In contrast, the base flow of Carlls River, which is in a part of southwestern Suffolk County served by storm sewers but not sanitary sewers, was reduced by only 10 percent during the same period. 


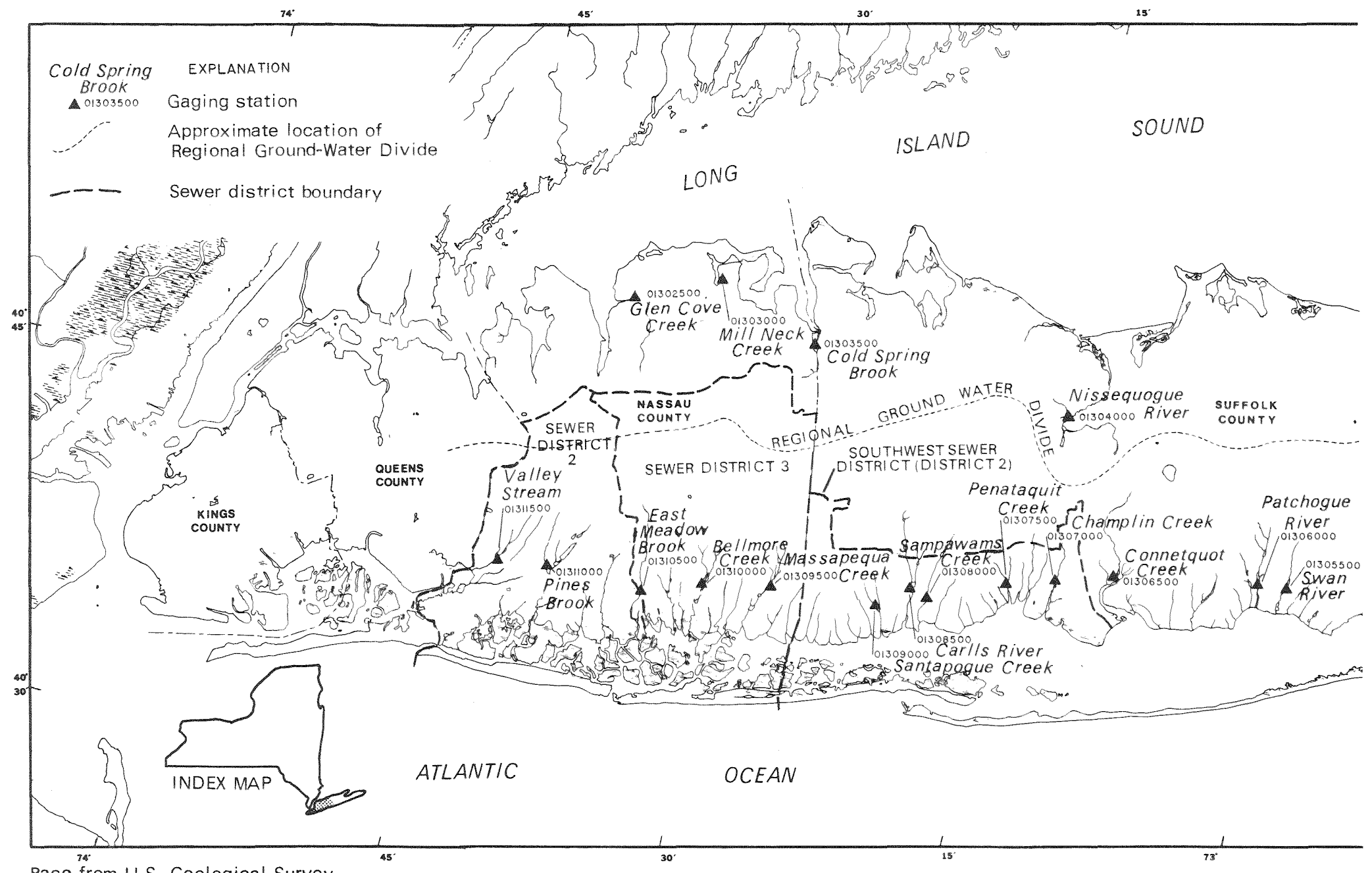

Seological Survey

State base map, 1974 


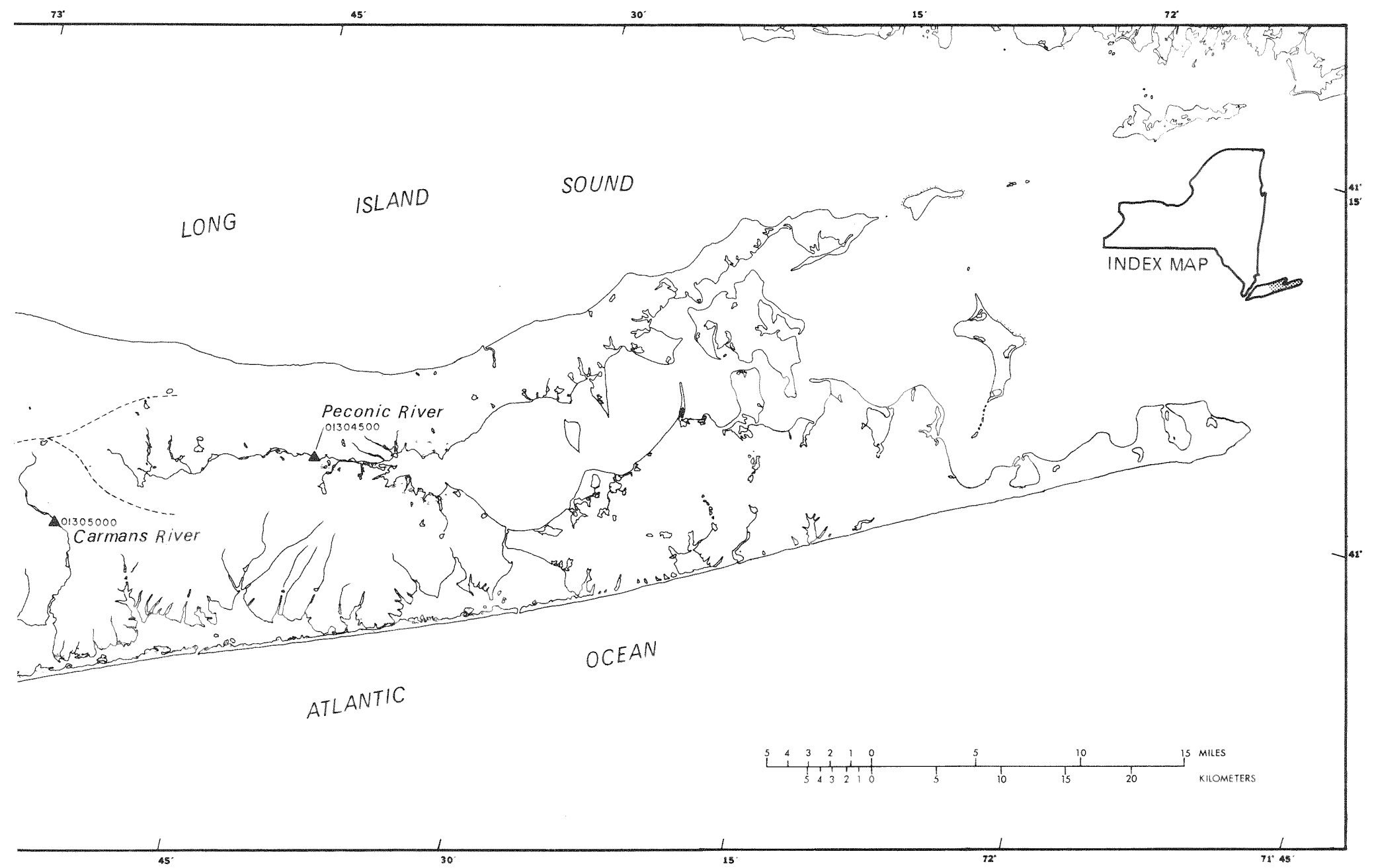

Figure 1.--Location of major geographic features, streams, and gaging stations used to obtain base-flow data. 


\section{Purpose and Scope}

The purpose of this report is to quantify the base flow of 19 continuously gaged Long Island streams during 1960-75, which includes the 1962-66 drought. These base-flow data will be used in calibrating computer models designed to predict the response of Long Island streams to hydrologic stresses such as the lowering of ground-water levels in response to large-scale sanitary sewering. The data will also be used to assess the long-term impact expected to result from storm- and sanitary-sewer systems on base flow of streams.

\section{REGIONAL HYDROGEOLOGY}

Long Island is underlain by unconsolidated Pleistocene and Cretaceous deposits that rest unconformably on a southward-sloping bedrock surface. Bedrock surface slopes from sea level in northwestern Queens County to about 2,000 feet below sea level in southeastern Suffolk County (fig. 2). The Cretaceous and Pleistocene deposits overlying this bedrock surface contain three major aquifers:

1. the Lloyd aquifer of late Cretaceous age, which directly overlies bedrock surface and is in turn overlain by the Raritan clay;

2. the Magothy aquifer of late Cretaceous age, which overlies the Raritan clay, and

3. the upper glacial aquifer of late Pleistocene age, which, in most places, overlies the Magothy aquifer.

In some areas of Long Island, a fourth aquifer, the Jameco aquifer of Pleistocene age, overlies the Magothy aquifer and is in turn overlain by the Gardiners Clay, also of Pleistocene age. Major features of the Long Island ground-water reservoir and their relative stratigraphic positions are shown in figure 2.

Detailed descriptions of Long Island's hydrogeology can be found in previous reports such as Cohen, Franke, and Foxworthy (1968), McClymonds and Franke (1972), and Franke and McClymonds (1972).

Under predevelopment conditions, all fresh ground water on Long Island would be derived directly from precipitation. At present, the ground-water reservoir is recharged from (1) infiltration of precipitation through unpaved areas; (2) infiltration of storm runoff through recharge basins, (3) injection of ground water used by industry through diffusion wells, and (4) infiltration and dispersion of domestic and industrial wastewater from cesspools, septic tanks, leaky sanitary sewer systems, and settling basins.

Ground water is discharged from the island by (1) seepage to streams; subsurface outflow to the bays, ocean, and Long Island Sound; and ( 3 ) evapotranspiration, which occurs principally near the shore. In addition, a significant quantity pumped for municipal, commercial, and domestic use is subsequently disposed of through sanitary sewers to tidewater. 
Long Island's ground-water system can be visualized as a regional flow system with a series of small subsystems, each of which is associated with a stream. These are depicted in cross section in figure 3. In the regional flow system, precipitation near the regional ground-water divide (fig. 1) moves downward into the saturated zone to recharge the upper glacial, Magothy, and Lloyd aquifers. The resulting hydraulic gradients are such that water in these aquifers moves downward and laterally away from the ground-water divide--northward toward Long Island Sound, and southward toward Great South Bay and the ocean.

The flow of shallow ground water in subsystems associated with streams on Long Island has been discussed by Franke and Cohen (1972) and Harbaugh and Getzen (1977). Pluhowski and Kantrowitz (1964) concluded, from hydraulic gradients beneath the streambed of Champlin Creek, that the flow of shallow ground water near Long Island streams is three dimensional with ground water moving both laterally and vertically upward into the stream. Flow beneath the stream at slightly greater depth becomes essentially horizontal under the regional hydraulic gradient and has little or no vertical component.



EXPLANATION

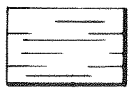

Clay

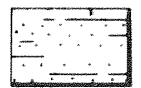

Sandy clay, clayey sand, and silt

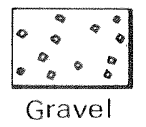

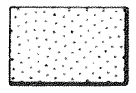

Sand

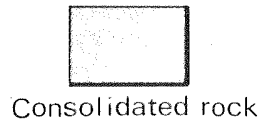

Figure 2.--Generalized cross section of Long Island showing major geologic features of the ground-water reservoir. (From Franke and MCClymonds, 1972)。 
An imaginary surface beneath each stream can be thought of as separating these two flow systems such that water above it will eventually enter the streambed, and water below it will remain in the regional flow system and ultimately discharge as undersea outflow. As seen in the map of East lleadow Brook (fig. 4), the junction of this surface with the water table upgradient from the stream forms a ground-water subsystem divide that separates water that will eventually enter the stream from water that will remain in the regional flow system. The location of this divide is inferred and shifts in response to changes in water-table configuration. Each stream subsystem is separated from the adjacent stream subsystem by an interstream ground-water divide (fig. 4), an approximately vertical plane similar to the regional ground-water divide but oriented north-south. These interstream divides also shift in response to changes in water-table gradient, and their exact locations cannot be delineated unless detailed information on ground-water levels between streams is available.

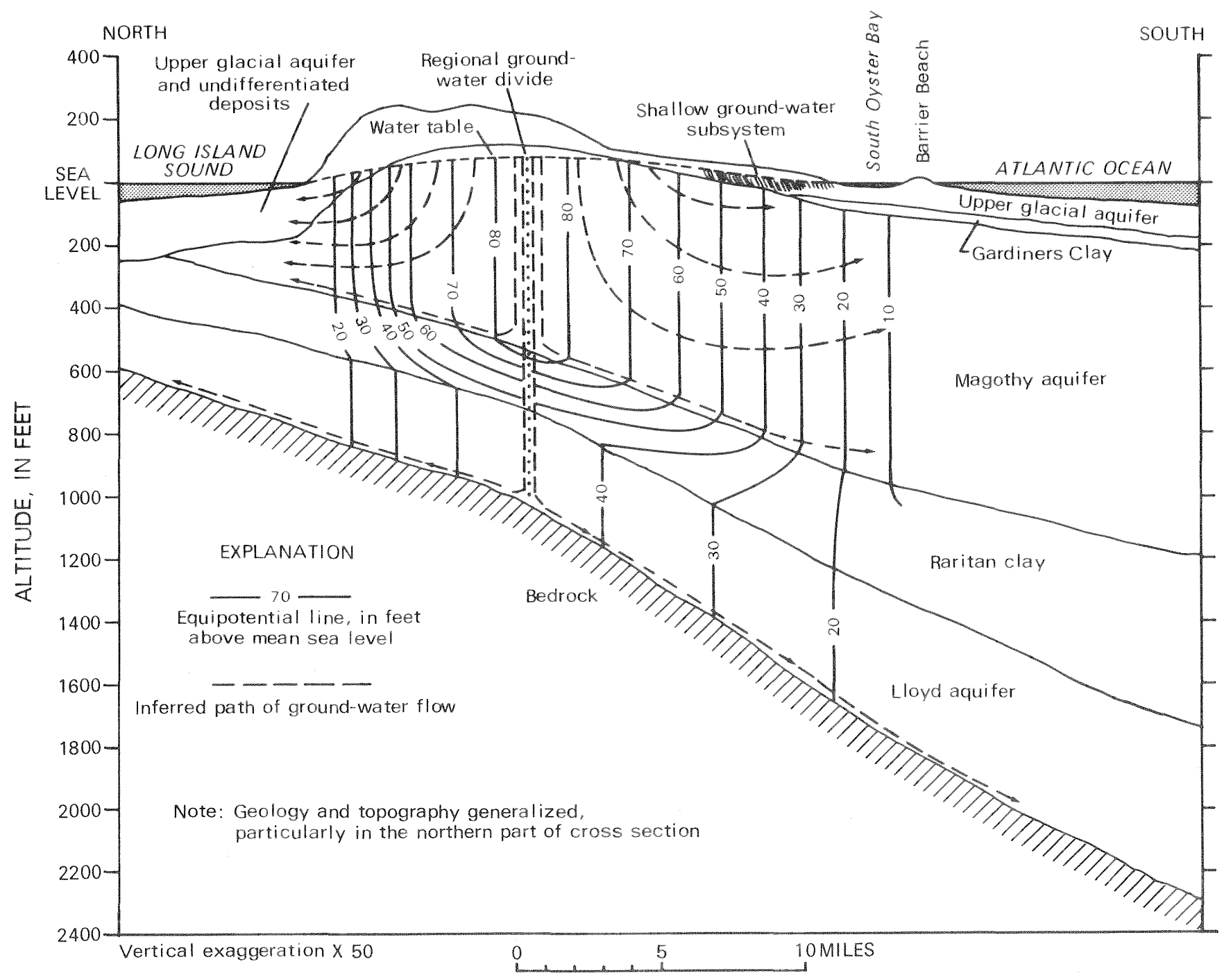

Figure 3.--Generalized equipotential and flow lines along a typical north-south cross section in the groundwater system of central Long Island under predevelopment conditions. (From Franke and Cohen, 1972). 


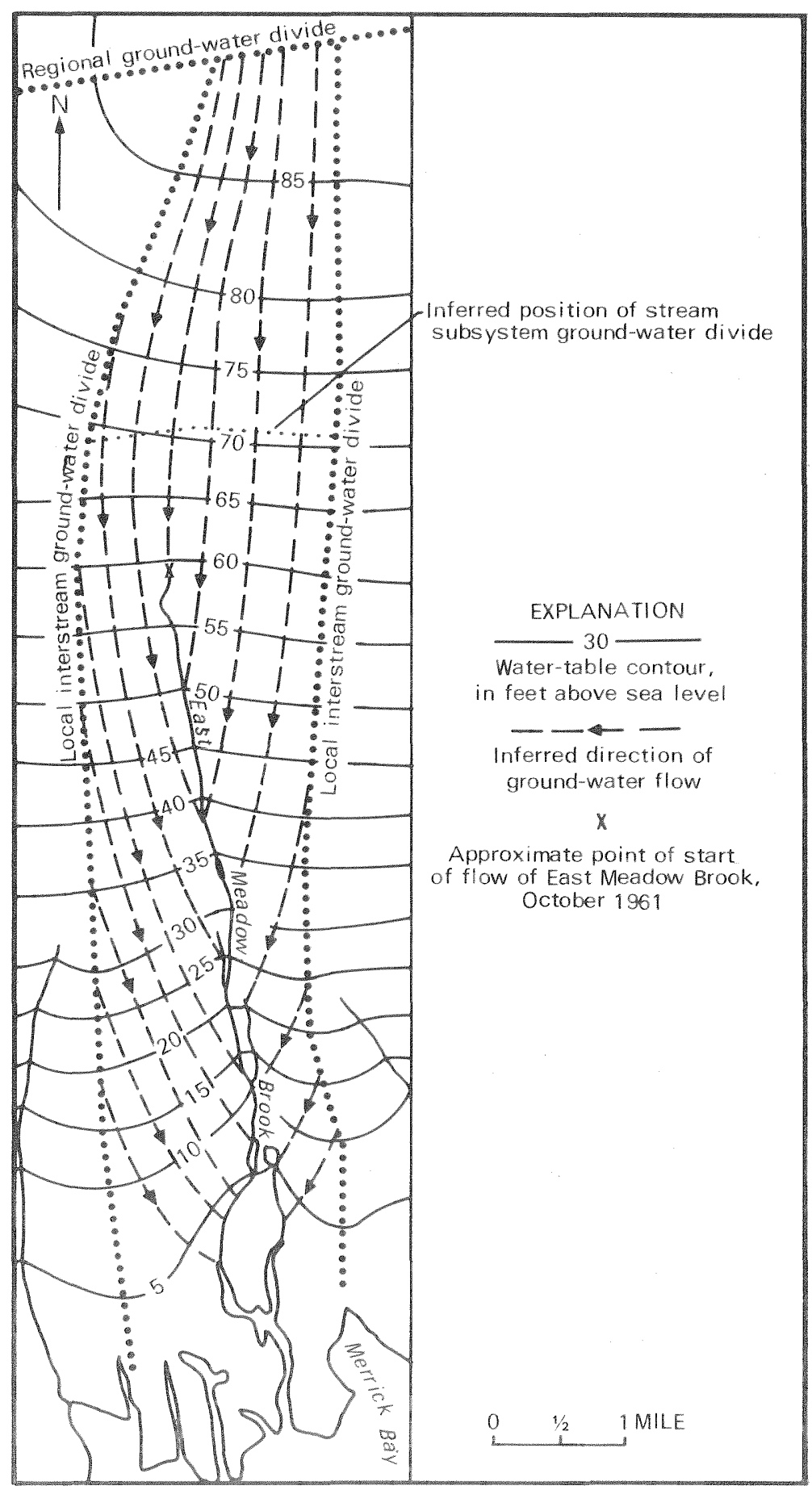

Figure 4:-Ground-water flow net in vicinity of East Meadow Brook, october 1961.

Location of stream is shown in fig. 1 . (Erom Franke and Cohen, 1972). 
The base flow of any Long Island stream as measured at a gaging station is proportional to the rate of ground-water seepage to the stream channel upstream from the gage. The rate of ground-water seepage is in turn controlled locally by the hydraulic gradients to the stream, the permeability of the streambed and nearby aquifer material, and the width and depth of the stream channel. As the water table fluctuates seasonally and in response to long-term variations in anounts of recharge, the hydraulic gradients to the stream change, and the resultant ground-water contribution to the stream responds accordingly.

\section{METHOD OF HYDROGRAPH SEPARATION}

To differentiate the base-flow component fron the surface-runoff component of Long Island streans, a method of hydrograph separation was used to estimate the increasing ground-water contribution to streams during precipitation events. The method is an adaptation of one described by Chow (1964) and is applicable to streams, such as those of Long Island, whose hydrographs generally exhibit pronounced storm peaks followed by several days of base flow.

The distribution of total flow in a strean during and after a given storm may be depicted in a single-peaked stream-discharge hydrograph (fig. 5). A discharge hydrograph of this type incorporates the two components of streamflow--direct runoff and ground-water discharge, or base flow. The curve in figure 5 contains three sections--the approach segment $A B$, the rising segment $B C$, and the recession segment CDEF. This hydrograph is the sum of the base-flow hydrograph and the direct-runoff hydrograph. During the storm, both base flow and direct runoff increase, peak, and then decrease; however, they do so at different rates. Base flow increases more slowly than direct runoff; thus the base-flow peak occurs some time after the direct runoff peak, commonly from 1 to 2 days later. The point of inflection (point D) during flow recession may occur anywhere from 1 to 2 days after the discharge peak (C). The lower part of the curve (segment EF), known as the "ground-water recession curve," depicts the decreasing rate of ground-water discharge to the stream after a rainfall. In general, segment EF will approximate a straight line when the hydrograph is plotted on semilogarithmic paper. This straight-line plot actually represents an exponential decrease of the ground-water contribution to the stream after direct runoff has ceased and will become generally equivalent in slope to the approach segment of the succeeding hydrograph peak.

Hydrograph separation entails differentiating the ground-water component of the hydrograph from the direct-runoff component. This is done under the assumption that bank storage on Long Island is negligible and that, like the tota1-flow hydrograph, the base-flow hydrograph consists of three segments; approach, rising, and recession. The approach segment for the base-flow hydrograph is an extension of the ground-water recession of the preceding hydrograph peak. This extension continues under the total flow hydrograph up to the point at which precipitation from the current storm reaches the water table and begins to increase the ground-water seepage (base flow) to the 
stream. The rising segment represents the increase in base flow resulting from the precipitation event, and the recession segment represents the subsequent base-flow recession and is taken as an extension of the ground-water recession segment of the total flow hydrograph.

In practice, the ground-water recession segment EF is extended back under the hydrograph peak to point G (fig. 5) which, for convenience, is located below the point of inflection, point $D$, on the recession curve. The prior ground-water recession approach segment $A B$ can be extended to the point $X$ (fig. 5), which represents the time at which the precipitation begins to cause an increase in ground-water seepage. Points $X$ and $G$ are connected by a straight line, and the resulting line BXGE approximates the base-flow hydrograph, with direct runoff above this line and base flow below it. It

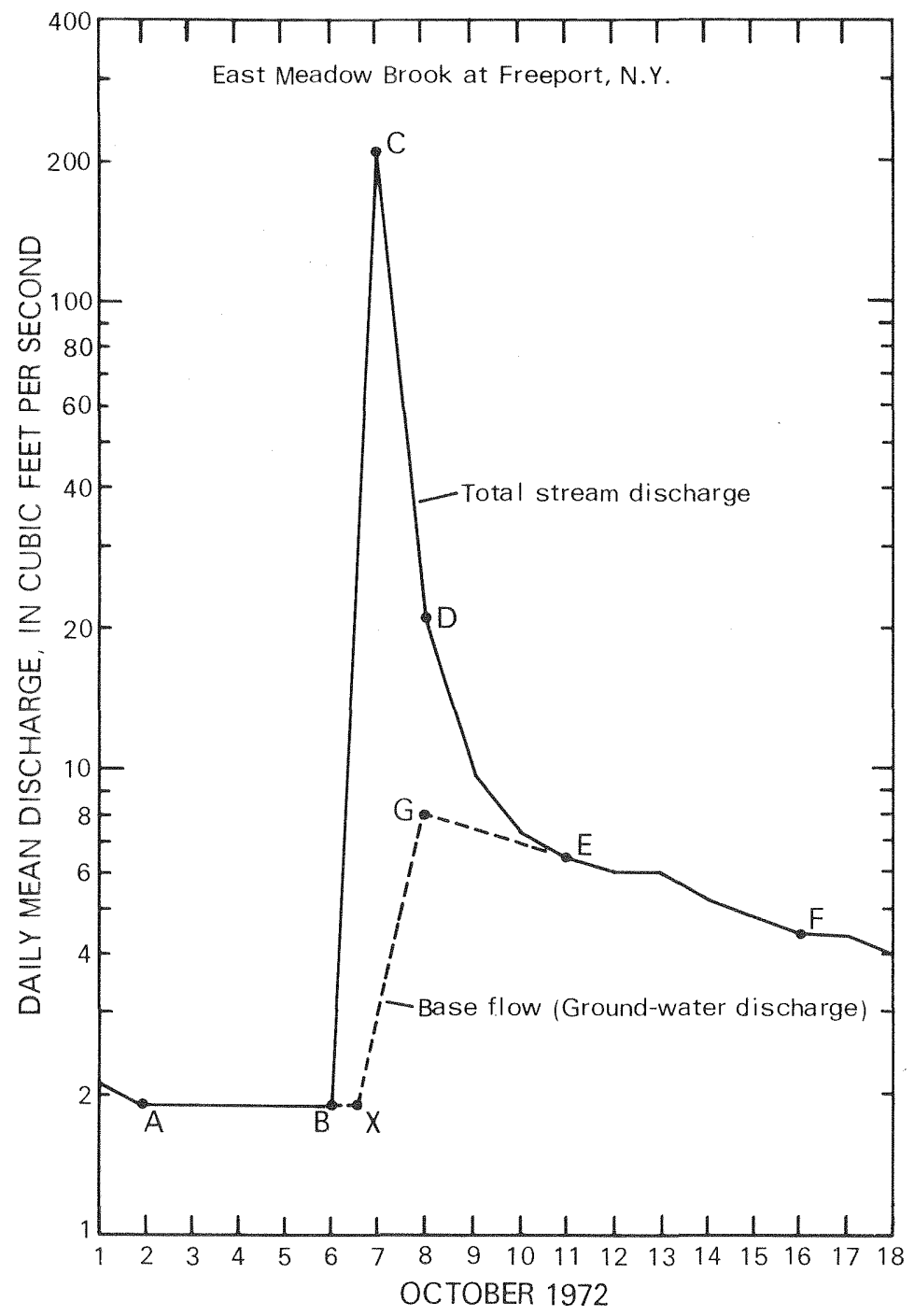

Figure 5.--Semilogarithmic plot of stream hydrograph for East Meadow Brook Freeport showing separation of base flow from direct runoff. 
should be noted that the location of point $X$, and therefore the distance BX, are difficult to define; moreover, the interval BX has a great effect on the actual quantity of base flow during the flow event. On Long Island, high infiltration rates allow the effects of precipitation to reach the water table quickly, which causes an increase in ground-water seepage in a relatively short time--possibly within hours. This time lag (distance BX in fig. 5) between the start of the precipitation event and the point at which ground-water seepage begins to increase is, for purposes of hydrograph separation, assumed to be less than 1 day.

It should also be noted that the placement of point $E$, the start of the ground-water recession segment, is also sometimes difficult to define, especially during compound flow events in which the ground-water recession is not readily apparent. The placement of this point can also have a great effect on the volume of base flow during a storm, even though the actual quantity is difficult, if not impossible, to determine. An example of hydrograph separation for compound flow events is given in figure 6.

The degree of precision to which the base-flow hydrograph can be delineated with this technique is reduced somewhat if daily mean discharge is used in place of hourly discharge, for example. However, daily mean discharges are published and readily available, whereas hourly discharges are not. Moreover, the use of hourly discharge would not significantly increase the accuracy of the mean monthly and mean annual base-flow figures published herein.

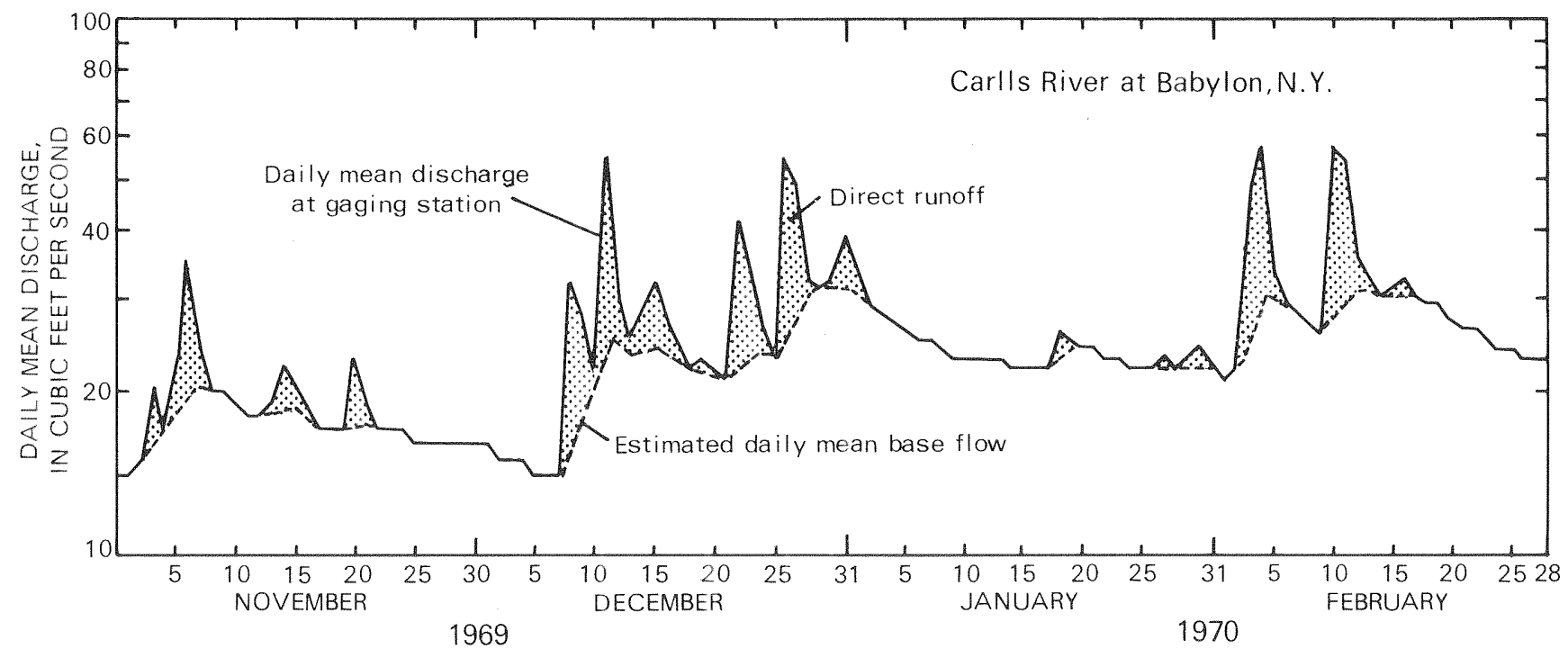

Figure 6.--Segment of daily mean discharge hydrograph for Carlls River showing base-flow separation. 


\section{LONG ISLAND BASE-FLOW DATA}

\section{Hydrograph Separation}

Daily mean discharge hydrographs for the 19 continuously gaged streams on Long Island during water years 1960-75 were obtained by semilogarithmic plotting of discharge data published annually by the U.S. Geological Survey (1960-75). (Locations of the streams and their gaging stations are shown in fig. 1.) Base flow was approximated on the hydrograph by the method shown in figure 5. Daily mean base-flow values were then taken from the resulting base-flow hydrograph and vere tabulated and averaged to obtain monthly mean base flow, in cubic feet per second. These values are given in table 2 (at end of report). The monthly mean base flows were then averaged to obtain an annual mean base flow for each stream during the sane period; these values are given in table 1. An example of a base-flow delineation on a segment of hydrograph for Carl.1s River is shown in figure 6 .

Where 1- to 2-week periods of record were missing, daily mean discharges estimated from values obtained from nearby streams were used to synthesize a hydrograph upon which base-flow separation could be done. Synthesized hydrographs were not used for long periods of missing record; rather, monthly mean discharges were estinated from correlations with nearby streams, and estimates of monthly mean base flow were obtained by comparison with records for periods immediately before and after the missing period.

On some Long Island streams, pond cleaning, fish-hatchery operations, and irrigation cause short-term regulation of streamflow that may appear on the stream hydrograph as fluctuations not associated with precipitation. To elininate the effect of stream regulation on estinates of base flow, discharge data simulating unregulated flow were substituted for these short periods of regulation. In addition, the base flows of certain streams were affected to an unknown degree by dewatering associated with sanitary-sewer construction or by nearby ground-water pumpage for public supply; these streams are footnoted in tables 1 and 2 (at end of report).

For comparison of selected streams with one another, monthly mean base flows of Connetquot and Carl1s Rivers and Massapequa Creek during 1960-75 are presented as hydrographs (fig. 7), which show the effect of the 1962-66 drought as well as seasonal fluctuations in base flow. These hydrographs also indicate that the monthly mean base flow of llassapequa Creek was affected to a greater degree during the drought years than the nonthly mean base flows of the Carlls or Connetquot Rivers. These differing responses reflect the severe lowering of ground-water levels near Massapequa Creek both fron a lack of natural recharge and the effects of sanitary sewering west of the creek. In contrast, Carlis River and ground-water levels near it were not affected by sanitary sewering but have been lowered somewhat by a reduction in natural recharge caused by routing of storm runoff to nearby streams. Connetquot River, affected neither by sanitary sewering nor storn sewering, had only a slight reduction in base flow during the drought. Calculation of the degree to which the drought, sanitary sewering, and storm sewering individually affected the base flow of various streams on Long Island is beyond the scope of this study but may be possible with ground-water flow models. 




Figure 7.--Monthly mean base-flow hydrograph for Connetquot River, Carlls River, and Massapequa Creek, water years 1960-75.

\section{Relationship of Base Flow to Flow Duration}

Cushing, Kantrowitz, and Taylor (1973, p. 35) have shown that stream discharge at the 50-percent duration point (median flow) of streams on the Delmarva Peninsula is approximately equal to annual mean base flow. To determine whether streams on Long Island exhibit a similar relationship, annual mean base flow of each of 17 streams was compared to discharge at various points for 50- to 70-percent duration on each stream's annual flow-duration curve through least-squares regression. (A flow-duration curve is a cumulative frequency curve that shows the percentage of time that a specified daily mean discharge is equaled or exceeded. For example, the flow at 55-percent duration is the flow that is equaled or exceeded 55 percent of the time; the time in this case is 1 year.) Cold Spring Brook and Valley Stream were excluded from the analysis because diversion and long periods of zero flow caused computation difficulties. Most of the duration-curve values were obtained through computer program A969 (Meeks, 1975). Discharges at points not calculated directly by the program were found by interpolation.

Discharge from the duration curves that most nearly equaled the annual mean base flows as defined herein were those at 55-percent duration. Annual mean base flows for the 17 streams are plotted against the respective annual 55-percent duration-point discharge in figure 8. The line through the points represents equality $(x=y$, slope $=1)$, which means that points on the line indicate no difference between base flow determined from hydrograph separation and annual discharge at 55-percent duration. 
A least-squares linear regression through the data points produces a regression line whose equation is:

$$
\begin{aligned}
\text { annual mean base flow }= & 0.0426 \mathrm{ft}^{3} / \mathrm{s}+[(0.9857) \times \text { flow } \\
& \text { at } 55 \text {-percent duration) }]
\end{aligned}
$$

This line is nearly the same as the equality line in figure 8. An analysis of variance produces an F-statistic (variance ratio) of 58,448, which, even at the 90-percent confidence level, is significant stastically. The correlation coefficient for the regression line is 0.9979 , indicating an almost perfect

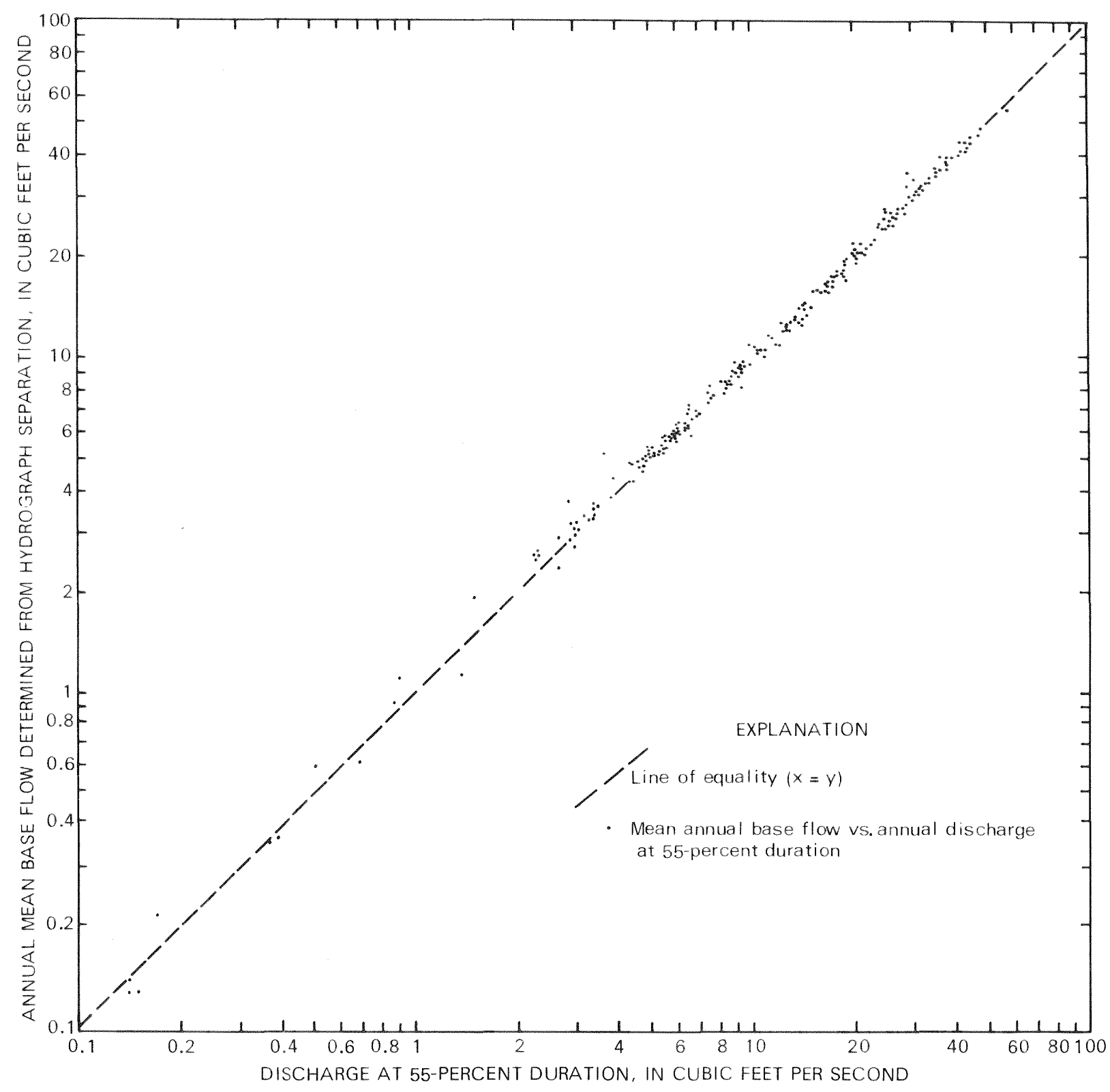

Figure 8.--Relationship between annual mean base flow and discharge at 55-percent duration for Long Island streams. 
correlation. The variance in the data is extremely sma11; the 95-percent confidence limits on the slope are $0.9857+0.008$, and the 95 -percent confidence intervals for the regression estimates of annual mean base flow are:

$$
\begin{aligned}
& 0.0426 \pm 0.152 \mathrm{ft}^{3} / \mathrm{s} \text { at the intercept; } \\
& 14.42 \pm 0.098 \mathrm{ft}^{3} / \mathrm{s} \text { at the mean; and } \\
& 49.238 \pm 0.30 \mathrm{ft}^{3} / \mathrm{s} \text { at } 50 \mathrm{ft} / \mathrm{s} \text {. }
\end{aligned}
$$

Both visual comparison (fig. 8) and regression analysis (eq. 1) indicate that the annual mean base flow of any stream on Long Island under nonurbanized or slightly urbanized conditions can be considered equal to the flow at 55-percent annual duration of that stream. The relationship between annual mean base flow and 55-percent duration seems close, even for streams affected by extreme urbanization or heavy ground-water pumpage (such as Pines Brook and Santapogue River). The greatest amount of point scatter (variance) in this relationship lies with data from Pines Brook and Santapogue River, both of which are characterized by little base flow during the year punctuated by large runoff peaks of short duration. Most of the scatter in these points is attributed to the imprecision in separating base flow on hydrographs of this type, although urbanization and ground-water pumpage may affect the accuracy of this relationship to some degree.

The apparent validity of the relationship shown in figure 8 offers a rapid and reliable means of estimating annual mean base flow and avoids the need for time-consuming hydrograph separation. The flow at 55-percent duration at gaging stations for a given period can be obtained quickly by processing daily mean discharges through a computer program; the flow at 55-percent duration at partial-record stations can normally be obtained by correlation with nearby gaged streams.

\section{SUMMARY}

Base flow data can be useful in water-use planning and management, particularly in calibrating digital computer models to predict the hydrologic effects of sewering or other stresses on the Long Island ground-water system.

Daily mean base flow was differentiated from daily mean discharge through hydrograph-separation procedures adapted from Chow (1964). The daily mean base-flow values were tabulated by month and averaged to obtain (a) monthly mean base flow, and (b) annual mean base flow, for each of the 19 streams on Long Island gaged from 1960-75. These monthly mean and annual mean base flow values are given in tables.

Discharges at the 55-percent duration point were found to closely approximate annual mean base flows of 17 of the 19 streams. This relationship can be used to estimate annual mean base flow under all but the most highly urbanized conditions and avoids the need for hydrograph separation.

The effect of the 1962-66 drought on the base flow of Long Island streams is evident as a downward trend in the hydrographs presented. 


\section{REFERENCES CITED}

Chow, V. T., 1964, Handbook of applied hydrology: New York, McGraw-Hi11, p. $14-2,14-13$.

Cohen, Philip, Franke, O. L., and Foxworthy, B. L., 1968, An atlas of Long Island's water resources: New York Water Resources Commission Bulletin $62,117 \mathrm{p}$.

Cushing, E. M., Kantrowitz, I. H., and Taylor, K. R., 1973, Water resources of the Delmarva Peninsula: U.S. Geological Survey Professional Paper 822, p. 33-35.

Franke, 0. L., and Cohen, Philip, 1972, Regional rates of ground-water movement on Long IsIand, New York, in Geological Survey Research 1972: U.S. Geological Survey Professiona1 Paper 800-C, p. C271-C277.

Franke, O. L., and McClymonds, N. E., 1972, Summary of the hydrologic situation on Long Island, New York, as a guide to water-management alternatives: U.S. Geological Survey Professional Paper 627-F, 59 p.

Harbaugh, A. W., and Getzen, R. T., 1977, Stream simulation in an analog model of the ground-water system on Long Island, N.Y.: U.S. Geological Survey Water Resources Investigations 77-58, $15 \mathrm{p}$.

McClymonds, N. E., and Franke, O. L., 1972, Water-transmitting properties of aquifers on Long Island, New York: U.S. Geological Survey Professional Paper 627-E, $24 \mathrm{p}$.

lleeks, W. C., 1975, Daily values statistics-program A969 in Watstore Users's Guide, V. 1, chapter 4: U.S. Geological Survey Open-File Report 75-426, p. G6-G16.

Pluhowski, E. J., and Kantrowitz, I. H., 1964, Hydrology of the Babylon-Islip area, Suffolk County, Long Island, New York: U.S. Geological Survey Water-Supply Paper 1768, p. 30-35.

Pluhowski, E. J., and Spinello, A. G., 1978, Impact of sewerage systems on stream base flow and ground-water recharge on Long Island, New York: U.S. Geological Survey Journal of Research, v. 6, no. 2, p. 263-271.

U.S. Geological Survey, 1962, Surface water supply of the United States, 1960, Part 1-B, North Atlantic slope basins, New York to York River: U.S. Geological Survey Water-Supply Paper 1702, p. 20-39.

, 1962-1976, Water resources data for New York, 1961-1975, Part 1, Surface water records: Albany, N.Y., U.S. Geological Survey open-file report (issued annually). 
Table 1.--Annual mean base flow of 19 continuously gaged

(All values are in cubic feet per second;

\begin{tabular}{|c|c|c|c|c|c|c|}
\hline Station number and name & 1960 & 1961 & 1962 & 1963 & 1964 & 1965 \\
\hline $\begin{array}{c}01302500 \text { - Glen Cove Creek at } \\
\text { Glen Cove }\end{array}$ & 5.14 & 6.12 & 5.12 & 4.22 & 3.84 & 3.34 \\
\hline $\begin{array}{c}01303000 \text { - Mill Neck Creek at } \\
\text { Mill Neck }\end{array}$ & 8.79 & 10.42 & 9.13 & 7.40 & 6.52 & 5.82 \\
\hline $\begin{array}{c}01303500 \text { - Cold Spring Brook at } \\
\text { Cold Spring Harbor } 1\end{array}$ & 4.61 & 4.77 & 5.32 & 3.86 & 3.00 & 2.42 \\
\hline $\begin{array}{c}01304000 \text { - Nissequogue River near } \\
\text { Smithtown }\end{array}$ & 41.06 & 45.01 & 43.28 & 40.92 & 35.97 & 33.09 \\
\hline $\begin{array}{c}01304500 \text { - Peconic River at } \\
\text { Riverhead }\end{array}$ & 36.62 & 39.53 & 39.29 & 33.03 & 28.07 & 24.87 \\
\hline 01305000 - Carmans River at & 25.75 & 25.52 & 26.47 & 26.05 & 20.40 & 17.80 \\
\hline $\begin{array}{c}01305500 \text { - Swan River at } \\
\text { East Patchogue }\end{array}$ & 13.05 & 13.83 & 13.86 & 12.61 & 11.38 & 10.41 \\
\hline $\begin{array}{r}01306000 \text { - Patchogue River } \\
\text { at Patchogue }{ }^{2}\end{array}$ & 20.48 & 21.05 & 22.53 & 19.64 & 18.25 & 17.66 \\
\hline $\begin{array}{c}01306500 \text { - Connetquot River } \\
\text { near Oakdale }\end{array}$ & 36.57 & 39.37 & 39.65 & 35.89 & 32.46 & 30.67 \\
\hline $\begin{array}{c}01307000 \text { - Champlin Creek } \\
\text { at Is lip }\end{array}$ & 6.83 & 7.88 & 7.04 & 6.02 & 5.80 & 5.08 \\
\hline $\begin{array}{c}01307500 \text { - Penataquit Creek } \\
\text { at Bay Shore }\end{array}$ & 5.31 & 6.50 & 6.29 & 6.08 & 5.83 & 5.14 \\
\hline $\begin{array}{r}01308000 \text { - Sampawams Creek } \\
\text { at Babylon }{ }^{3}\end{array}$ & 9.24 & 11.59 & 9.61 & 8.32 & 7.74 & 6.79 \\
\hline $\begin{array}{c}01308500 \text { - Car11s River at } \\
\text { Babylon }\end{array}$ & 24.38 & 30.53 & 26.97 & 25.74 & 21.67 & 17.41 \\
\hline $\begin{array}{c}01309000 \text { - Santapogue Creek } \\
\text { at Lindenhurst } 2,3\end{array}$ & 5.12 & 5.44 & 3.70 & 3.18 & 2.58 & 1.90 \\
\hline $\begin{array}{r}01309500 \text { - Massapequa Creek } \\
\text { at Massapequa }{ }^{4}, 5\end{array}$ & - & 16.20 & 12.08 & 9.21 & 7.29 & 5.20 \\
\hline $\begin{array}{r}01310000 \text { - Bellmore Creek } \\
\text { at Bellmore }\end{array}$ & 12.47 & 17.57 & 14.08 & 10.91 & 10.74 & 5.75 \\
\hline $\begin{array}{c}01310500 \text { - East Meadow Brook } \\
\text { at Freeport }\end{array}$ & 13.07 & 19.43 & 15.84 & 10.93 & 8.08 & 4.34 \\
\hline $\begin{array}{c}01311000 \text { - Pines Brook at } \\
\text { Malverne }\end{array}$ & 2.76 & 3.54 & 2.36 & 1.14 & .60 & .22 \\
\hline $\begin{array}{r}01311500 \text { - Valley Stream at } \\
\text { Valley Stream }\end{array}$ & 2.76 & 3.49 & 1.88 & .72 & .33 & .04 \\
\hline
\end{tabular}

* Five-month average, October 1969 through February 1970.

Includes diversion through hatchery.

Dashes denote gage not in service.

Indeterminate effect on annual base flow caused by 1 local ground-water pumpage.

Gage in service only 2 months during water year 1960 . 


\begin{tabular}{|c|c|c|c|c|c|c|c|c|c|c|}
\hline Name & 1966 & 1967 & 1968 & 1969 & 1970 & 1971 & 1972 & 1973 & 1974 & 1975 \\
\hline Glen Cove & 3.23 & 2.87 & 3.02 & 3.30 & 3.03 & 2.95 & 3.35 & 4.30 & 4.66 & 4.80 \\
\hline Mi11 Neck & 5.13 & 5.03 & 5.44 & 5.59 & 6.15 & 5.69 & 6.72 & 8.77 & 9.03 & 8.41 \\
\hline Cold Spring & 1.44 & 1.15 & 1.18 & 1.63 & 2.47 & 2.84 & 2.60 & 4.12 & 4.87 & 4.63 \\
\hline Nissequogue & 26.10 & 27.15 & 31.98 & 30.38 & 38.07 & 34.86 & 34.71 & 47.38 & 43.45 & 41.93 \\
\hline Peconic & 15.69 & 22.07 & 25.99 & 24.43 & 33.75 & 27.20 & 32.32 & 55.73 & 43.48 & 40.43 \\
\hline Carmans & 12.71 & 12.58 & 16.60 & 15.61 & 19.42 & 16.74 & 17.34 & 29.34 & 27.86 & 24.62 \\
\hline Swan & 10.07 & 10.70 & 9.60 & 9.32 & 10.77 & 9.35 & 10.54 & 14.15 & 12.05 & 12.01 \\
\hline Patchogue & 14.19 & 16.18 & 17.61 & 15.78 & - & - & - & - & 19.65 & 19.09 \\
\hline Connetquot & 24.11 & 27.46 & 31.00 & 28.79 & 34.15 & 29.70 & 31.59 & 46.02 & 37.43 & 32.27 \\
\hline Champlin & 3.61 & 5.31 & 5.39 & 5.23 & - & - & - & - & - & - \\
\hline Penataquit & 3.67 & 5.25 & 5.14 & 5.90 & 5.96 & 5.15 & 5.83 & 7.58 & 5.64 & 6.19 \\
\hline Sampawams & 5.22 & 7.35 & 6.24 & 6.21 & 8.78 & 6.35 & 8.36 & 10.66 & 8.16 & 13.34 \\
\hline $\operatorname{Car} 11 \mathrm{~s}$ & 12.66 & 17.96 & 16.80 & $17 \cdot 60$ & 20.48 & 15.78 & 20.28 & 27.06 & 21.75 & 24.38 \\
\hline Santapogue & 1.18 & 2.48 & 2.03 & 1.88 & - & - & - & - & - & - \\
\hline Massapequa & 2.55 & 4.92 & 5.42 & 5.73 & 7.70 & 4.92 & 7.00 & 16.29 & 6.97 & 9.56 \\
\hline BelImore & 2.90 & 5.85 & 6.20 & 5.99 & 6.11 & 4.98 & 9.12 & 12.53 & 8.09 & 10.62 \\
\hline East Meadow & .95 & 2.62 & 4.59 & 7.82 & 6.98 & 3.19 & 4.87 & 10.09 & 5.73 & 8.24 \\
\hline Pines & 0 & .12 & .13 & .13 & $.17 \%$ & .01 & .14 & .62 & .36 & .37 \\
\hline Valley & 0 & .13 & 0 & .15 & .27 & .04 & .05 & .38 & .02 & .06 \\
\hline
\end{tabular}

5 Annual values for water years 1970 and 1973 reflect base-flow augmentation to unknown degree through dewatering activities associated with sewer construction.

6 Annual values for water years 1974 and 1975 reflect basemlow augmentation to unknown degree through dewatering activities associated with sewer construction. 


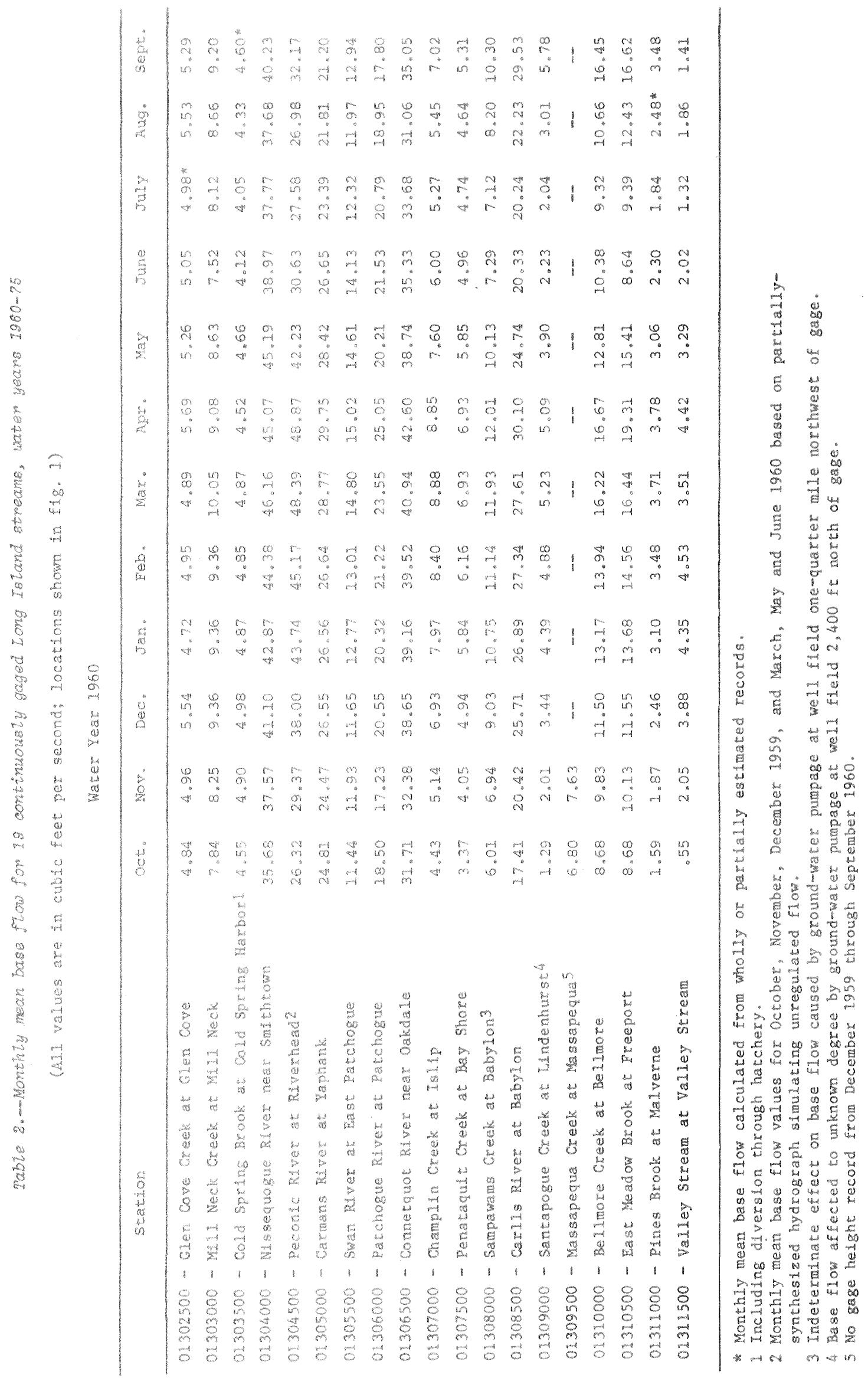


Water Year 1961

\begin{tabular}{|c|c|c|c|c|c|c|c|c|c|c|c|c|}
\hline Station & oct. & Nov. & Dec. & Jan. & Feb. & Mar. & Apr. & May & June & July & Aug. & Sept. \\
\hline 01302500 - Glen Cove Creek at Glen Cove & 4.68 & 4.96 & 5.50 & $6.11 *$ & $7.63 *$ & 7.20 & 7.32 & 6.35 & 6.02 & 6.03 & 6.08 & 5.56 \\
\hline 01303000 - Mill Neck Creek at Mill Neck & 9.33 & 9.64 & 9.96 & 9.94 & 10.81 & 11.44 & 12.05 & 11.52 & 10.66 & 10.32 & 9.92 & 9.39 \\
\hline 01303500 - Cold Spring Brook at Cold Spring Harbor 1 & 4.24 & 4.26 & 3.88 & 4.24 & 5.00 & 4.55 & 5.35 & 5.12 & 4.82 & $5.16 *$ & 5.63 & $4.97 *$ \\
\hline 01304000 - Nissequogue River near Smithtown & 42.13 & 41.80 & 42.03 & $45.26 *$ & 45.71 & 48.87 & 51.23 & 49.39 & 44.87 & 43.23 & 43.35 & 42.27 \\
\hline 01304500 - Peconic River at Riverhead 2 & 35.73 & 35.23 & 32.61 & 32.98 & 30.70 & 50.84 & 53.10 & 55.48 & 44.23 & 36.65 & 34.19 & 32.57 \\
\hline 01305000 - Carmans River at Yaphank & 22.19 & 21.57 & 21.58 & 22.73 & 24.11 & 28.26 & 29.15 & 29.79 & 28.28 & 27.44 & 26.66 & 24.50 \\
\hline 01305500 - Swan River at East Patchogue & $12.34 *$ & $11.21 *$ & 11.32 & 12.44 & 12.73 & 15.48 & $15.55 *$ & 15.48 & 15.95 & 14.89 & 13.88 & 14.69 \\
\hline 01306000 - Patchogue River at Patchogue & $17.12 *$ & $19.36 *$ & 17.51 & 19.15 & 19.55 & 22.61 & 22.75 & 24.65 & 24.65 & 22.29 & 22.18 & 20.73 \\
\hline 01306500 - Connetquot River near Oakdale & 33.84 & 32.73 & 30.97 & $35.03 *$ & $38.32 *$ & 47.00 & 46.30 & 45.97 & 41.87 & $41.58 *$ & 42.13 & 36.67 \\
\hline 01307000 - Champlin Creek at Islip & 7.09 & 6.65 & 6.84 & $7.64 *$ & $7.85 *$ & 11.27 & 9.83 & 9.47 & 7.99 & 7.32 & 7.15 & $5.40 *$ \\
\hline 01307500 - Penataquit Creek at Bay Shore & 5.10 & 5.53 & 5.20 & $6.16 *$ & $6.58 *$ & 9.00 & 8.65 & 7.89 & 6.40 & 5.99 & 6.25 & 5.26 \\
\hline 01308000 - Sampawams Creek at Babylon ${ }^{3}$ & 9.85 & 9.91 & 9.32 & 9.72 & 10.34 & 15.69 & 16.02 & 15.25 & 12.27 & 10.42 & 11.17 & 9.08 \\
\hline 01308500 - Carlls River at Babylon & 28.47 & 29.12 & 26.77 & $28.69 *$ & $31.29 *$ & 40.29 & 37.33 & 35.87 & 29.83 & 27.32 & 27.85 & 23.58 \\
\hline 01309000 - Santapogue Creek at Lindenhurst ${ }^{4}$ & 4.64 & 4.68 & 3.77 & 4.37 & 4.65 & 8.85 & 8.45 & 8.45 & 5.85 & 4.10 & 4.62 & 2.80 \\
\hline 01309500 - Massapequa Creek at Massapequa 5 & 11.96 & 13.11 & 11.78 & 12.96 & 13.92 & 22.62 & 23.73 & 23.11 & 16.45 & 13.68 & 17.48 & 13.65 \\
\hline 01310000 - Bellmore Creek at Bellmore & 15.55 & 16.09 & 15.78 & 17.15 & $17.87 *$ & 21.97 & 22.28 & 21.10 & 15.57 & 13.32 & 18.11 & 16.04 \\
\hline 01310500 - East Meadow Brook at Freeport & 15.42 & 16.52 & 15.36 & 16.74 & 18.07 & 24.34 & 26.93 & 24.74 & 18.83 & 16.58 & 22.10 & 17.53 \\
\hline 01311000 - Pines Brook at Malverne & 2.31 & 2.58 & 2.46 & $2.99 *$ & $3.29 *$ & 4.54 * & 5.62 & 5.45 & 3.90 & 2.99 & 3.70 & 2.61 \\
\hline 01311500 - Valley Stream at Valley Stream & 4.53 & 3.02 & 2.49 & 2.92 & 2.81 & 4.58 & 6.15 & 4.86 & 3.07 & 2.12 & 3.63 & 1.71 \\
\hline
\end{tabular}

* Monthly mean base flow calculated from wholly or partially estimated records.

1 Including diversion through hatchery.

2 Monthly mean base flow for October, November, December 1960, and May, June 1961 based on partially-

synthesized hydrograph simulating unregulated flow.

3 Indeterminate effect on base flow caused by ground-water pumpage at well field one-quarter mile northwest of gage.

4 Base flow affected to unknown degree by ground-water pumpage at well field 2,400 ft north of gage.

5 No gage height record from October 1960 through February 1961. Monthly mean base flow values for this period are

based on estimated monthly mean discharges for Massapequa Creek. 
Table 2.--Monthiy mean base flow for 19 continuously gaged Long Island streams, water years 1960-75 (continued)

Water Year 1962

\begin{tabular}{|c|c|c|c|c|c|c|c|c|c|c|c|c|c|}
\hline & Station & oct. & Nov. & Dec. & Jan. & Feb. & Mar. & Apr. & May & June & July & Aug. & sept. \\
\hline 01302500 & - Glen Cove Creek at Glen Covel & 5.34 & 5.28 & 5.60 & 5.84 & 5.40 & 6.33 & 5.73 & 4.75 & 4.76 & 4.39 & 4.25 & 3.79 \\
\hline 01303000 & - Mil1 Neck Creek at Mi11 Neck & 9.74 & 9.78 & 9.71 & 10.07 & 9.76 & 10.36 & 9.77 & $8.85 *$ & 8.19 & 7.50 & 8.01 & 7.77 \\
\hline 01303500 & - Cold Spring Brook at Cold Spring Harbor 2 & 5.20 & $5.42 *$ & 5.68 & $6.07 *$ & $5.71 *$ & 6.10 & $5.45 *$ & 5.20 & $4.95 *$ & $4.51 *$ & 4.67 & 4.85 \\
\hline 01304000 & - Nissequogue River near Smithtown & 40.23 & 40.47 & 42.10 & 46.87 & 47.39 & 51.74 & 49.33 & 43.81 & 40.97 & 36.77 & 40.74 & 38.97 \\
\hline 01304500 & - Peconic River at Riverhead & 36.74 & 31.57 & 32.02 & 46.26 & 46.07 & 64.13 & 56.83 & 42.77 & 33.53 & 27.74 & 24.29 & 29.50 \\
\hline 01305000 & - Carmans River at Yaphank & 24.52 & 24.54 & 22.98 & 28.76 & 30.07 & 31.98 & 28.67 & 27.65 & 25.25 & 25.15 & 23.50 & 24.60 \\
\hline 01305500 & - Swan River at East Patchogue & $15.55 *$ & $15.08 *$ & 12.76 & 14.55 & 15.00 & 15.76 & $15.62 *$ & $13.16 *$ & 12.25 & $12.87 *$ & 12.37 & 11.36 \\
\hline 01306000 & - Patchogue River at Patchogue & 23.42 & 22.83 & 21.16 & 22.82 & 24.09 & 26.03 & 26.64 & 23.41 & 21.58 & $19.85 *$ & $19.43 *$ & 19.07 \\
\hline 01306500 & - Connetquot River near Oakdale & 36.26 & 37.33 & 37.55 & 43.53 & 42.50 & 52.08 & 46.83 & 40.77 & 37.27 & 35.58 & 34.06 & 32.00 \\
\hline 01307000 & - Champlin Creek at Is $11 p$ & 5.89 & 5.56 & 6.42 & 8.72 & 8.20 & 10.83 & 9.64 & 7.12 & 6.47 & 5.46 & 5.27 & 4.87 \\
\hline 01307500 & - Penataquit Creek at Bay Shore & 5.16 & 5.05 & 5.56 & 7.43 & 7.20 & 9.89 & 8.81 & 6.46 & 5.44 & 4.25 & 5.04 & 5.16 \\
\hline 01308000 & - Sampawams Creek at Babylon 3 & 9.29 & 8.31 & 8.88 & 11.89 & 11.50 & 16.42 & 13.62 & 9.06 & 7.16 & 6.66 & 6.65 & 5.93 \\
\hline 01308500 & - Car11s River at Babylon & 23.06 & 22.25 & 26.21 & 33.85 & 33.52 & 39.61 & 33.10 & 25.03 & 21.30 & 20.65 & 22.87 & 22.13 \\
\hline 01309000 & - Santapogue Creek at Lindenhurst 4 & 2.61 & 2.68 & 3.27 & 5.29 & 4.45 & $8.37 *$ & $6.80^{*}$ & 3.55 & 2.22 & 1.61 & 1.67 & 1.90 \\
\hline 01309500 & - Massapequa Creek at Massapequa & $12.87 *$ & $11.67 *$ & 11.72 & 15.19 & 14.23 & 20.06 & 17.40 & $10.20 *$ & 8.80 & 7.25 & 7.85 & 7.70 \\
\hline 01310000 & - Bellmore Creek at Bellmore & 14.18 & 13.32 & 14.28 & 17.56 & 17.05 & 22.26 & 19.52 & 13.19 & 9.58 & 9.07 & 9.85 & 9.11 \\
\hline 01310500 & - East Meadow Brook at Freeport & 18.58 & 15.80 & 16.47 & 18.76 & 18.21 & 22.97 & 22.50 & 16.09 & 12.56 & 9.91 & 9.76 & 8.47 \\
\hline 01311000 & - Pines Brook at MaIverne & 2.89 & 2.46 & 2.62 & 2.94 & 3.28 & 4.08 & 3.38 & 2.25 & 1.47 & 1.01 & 1.03 & .92 \\
\hline 01311500 & - Valley Stream at Valley Stream & 2.17 & 1.26 & 1.28 & 2.51 & 3.24 & 4.70 & 3.62 & 1.54 & .96 & .49 & .55 & .27 \\
\hline
\end{tabular}

* Monthly mean base flow calculated from wholly or partially estimated records.

I Monthly mean base flow for Glen Cove Creek based on hydrograph from which unknown discharge has been separated.

2 Including diversion through hatchery.

3 Indeterminate effect on base flow caused by ground-water pumpage at well field one-quarter mile northwest of gage.

4 Base flow affected to unknown degree by ground-water pumpage at well field 2,400 ft north of gage. 
Water Year 1963

\begin{tabular}{|c|c|c|c|c|c|c|c|c|c|c|c|c|}
\hline Station & Oct。 & Nov. & Dec. & $\operatorname{Jan}$. & Feb. & Mar. & Apr. & May & June & July & Aug. & Sept. \\
\hline 01302500 - Glen Cove Creek at Glen Covel & 4.21 & 4.43 & 4.11 & 4.17 & 4.36 & 5.02 & 4.34 & 4.43 & 4.20 & 4.08 & 3.78 & 3.53 \\
\hline 01303000 - Mil1 Neck Creek at Mil1 Neck & 8.43 & 8.99 & 8.02 & 7.78 & 7.78 & 9.32 & 6.98 & 6.97 & 6.37 & 5.98 & 6.05 & 6.15 \\
\hline 01303500 - Cold Spring Brook at Cold Spring Harbor 2 & 4.41 & 4.11 & 4.32 & 4.34 & 3.60 & 3.71 & 4.01 & 4.07 & 3.89 & 3.51 & 3.33 & 2.97 \\
\hline 01304000 - Nissequogue River near Smithtown & 41.07 & $42.70 *$ & $40.36 *$ & 44.13 & 47.50 & 50.19 & 43.32 & 43.03 & 38.73 & 35.66 & 32.84 & 31.55 \\
\hline 01304500 - Peconic River at Riverhead & 27.10 & 35.17 & 36.94 & 32.52 & 39.14 & 52.36 & 39.70 & 34.13 & 33.17 & 23.65 & 23.74 & 18.72 \\
\hline 01305000 - Carmans River at Yaphank & $25.77 *$ & $28.23 *$ & 27.77 & 26.18 & $28.70 *$ & 31.00 & 28.67 & 26.16 & 25.90 & 23.10 & 20.98 & 20.19 \\
\hline 01305500 - Swan River at East Patchogue & 12.08 & 12.19 & 12.82 & 13.43 & 13.32 & 15.00 & 13.97 & 13.00 & 12.15 & 11.57 & 11.07 & 10.77 \\
\hline 01306000 - Patchogue River at Patchogue & 18.61 & 19.30 & 20.45 & 19.73 & 21.16 & 23.08 & 21.48 & 20.65 & 19.30 & 18.69 & 16.10 & 17.07 \\
\hline 01306500 - Connetquot River near Oakdale & $37.65 *$ & 40.17 & 38.29 & 35.60 & 36.88 & 45.53 & 37.47 & 35.37 & 36.67 & 32.02 & 28.65 & 26.32 \\
\hline 01307000 - Champlin Creek at Is1ip & 5.18 & 6.08 & 7.25 & 6.74 & 8.09 & 9.02 & 7.07 & 6.09 & 5.23 & 3.88 & 3.73 & 3.85 \\
\hline 01307500 - Penataquit Creek at Bay Shore & 5.30 & 5.89 & 6.33 & 6.09 & 6.94 & 8.68 & 7.74 & 6.29 & 5.02 & 4.77 & 5.30 & 4.60 \\
\hline 01308000 - Sampawams Creek at Babylon 3 & 7.26 & 8.79 & 9.99 & 9.19 & 10.23 & 13.87 & 9.46 & 7.87 & 7.17 & 5.68 & 5.44 & 4.93 \\
\hline 01308500 - Car11s River at Babylon & $26.35 *$ & $27.75 *$ & $29.71 *$ & $28.67 *$ & $32.00^{*}$ & $36.52 *$ & 28.37 & 24.53 & 23.48 & 18.24 & 16.87 & 16.38 \\
\hline 01309000 - Santapogue Creek at Lindenhurst 4 & 2.54 & 3.59 & 3.97 & $3.27 *$ & $4.43^{*}$ & 6.56 & 4.74 & 2.80 & 2.51 & 1.36 & 1.26 & $1.18^{*}$ \\
\hline 01309500 - Massapequa Creek at Massapequa & 9.40 & 11.03 & 10.84 & 10.48 & 10.15 & 16.13 & 10.95 & $8.95 *$ & $7.83 *$ & 5.17 & 4.85 & 4.71 \\
\hline 01310000 - Bellmore Creek at Bellmore & 12.08 & 12.98 & 12.67 & 12.03 & 13.51 & 16.13 & 12.04 & 9.11 & 8.91 & 6.98 & 7.35 & 7.16 \\
\hline 01310500 - East Meadow Brook at Freeport5 & 9.95 & $12.22 *$ & $13.33 *$ & $12.58^{*}$ & $12.29 *$ & $18.55 *$ & $12.30 *$ & $11.37 *$ & $10.95 *$ & $7.00^{*}$ & $5.72 *$ & $4.84 *$ \\
\hline 01311000 - Pines Brook at Malverne & 1.27 & 1.56 & 1.65 & 1.39 & 1.78 & 2.39 & 1.54 & 1.08 & .626 & .189 & .122 & .097 \\
\hline 01311500 - Valley Stream at Valley Stream6 & .543 & 1.06 & 1.11 & .76 & 1.15 & 1.95 & 1.00 & .612 & .397 & .026 & .020 & .004 \\
\hline
\end{tabular}

* Monthly mean base flow calculated from wholly or partially estimated records.

1 Monthly mean base flow for Glen Cove Creek based on hydrograph from which unknown discharge has been separated.

2 Including diversion through hatchery.

3 Indeterminate effect on base flow caused by ground-water pumpage at well fleld one-quarter mile northwest of gage.

4 Base flow affected to unknown degree by ground-water pumpage at well field 2,400 ft north of gage,

5 Monthly mean base flow for East Meadow Brook calculated from a synthesized hydrograph correlated with Massapequa Creek.

6 Monthly mean base flow for Valley Stream from July, August 1963 based on periods of doubtful gage height record. 
Tabte 2.--Monthiy mean base flow for 19 continuously gaged Long Istand streams, water years 1960-75 (continued)

Water Year 1964

\begin{tabular}{|c|c|c|c|c|c|c|c|c|c|c|c|c|}
\hline Station & oct. & Nov. & Dec. & Jan. & Feb. & Mar. & Apr. & May & June & JuIY & Aug. & Sept. \\
\hline 01302500 - Glen Cove Creek at Glen Cove & 4.06 & 4.04 & 3.84 & 4.35 & 3.91 & 3.87 & 4.37 & 3.82 & 3.63 & 3.59 & 3.23 & 3.41 \\
\hline 01303000 - Mill Neck Creek at Mill Neck & 5.87 & 7.27 & 7.16 & 7.50 & 7.22 & 6.70 & 7.16 & 6.19 & 6.03 & 6.06 & 5.53 & 5.59 \\
\hline 01303500 - Cold Spring Brook at Cold Spring Harborl & $3.13 *$ & 2.93 & 3.31 & 3.43 & 3.50 & 3.38 & 3.49 & 3.07 & 2,70 & 2.52 & 2.37 & 2.20 \\
\hline 01304000 - Nissequogue River near Smithtown & 30.58 & $32.53 *$ & 35.52 & 37.64 & 39.90 & 41.13 & 44.83 & 39.61 & 36.43 & 33.74 & 30.58 & 29.20 \\
\hline 01304500 - Peconic River at Riverhead & 17.83 & $20.18 *$ & 23.13 & 27.47 & 32.60 & 36.92 & $49.73 *$ & 43.35 & 25.30 & 23.80 & 18.92 & 17.57 \\
\hline 01305000 - Carmans River at Yaphank & 19.90 & 20.38 & 17.95 & 17.25 & 19.62 & 22.45 & 26.96 & 25.43 & 20.30 & 19.77 & 17.83 & 16.90 \\
\hline 01305500 - Swan River at East Patchogue & 10.55 & 10.73 & 9.90 & 10.66 & 11.00 & 11.57 & 13.86 & 14.36 & 12.22 & 11.48 & 10.37 & 9.90 \\
\hline 01306000 - Patchogue River at Patchogue & 15.15 & $14.51 *$ & $15.51 *$ & 17.18 & 18.62 & 18.81 & 23.38 & 23.74 & 20.02 & 18.67 & 17.22 & 16.24 \\
\hline 01306500 - Connetquot River near Dakdale & 27.16 & $32.96 *$ & $30.70 *$ & $34.32 *$ & 34,17 & $32.54 *$ & $41.93 *$ & 39.70 & 32.10 & 29.83 & 29.03 & 25.06 \\
\hline 01307000 - Champlin Creek at Islip & 3.59 & 4.40 & 5,35 & 6.33 & 6.77 & 7.17 & 9.54 & 7.45 & 5.41 & 5.29 & 4.41 & 3.90 \\
\hline 01307500 - Penataquit Creek at Bay Shore & 4.13 & 4.84 & 5.23 & 6.32 & 6.92 & 7.00 & 8.27 & 6.95 & 5.70 & 5.55 & 4.61 & 4.38 \\
\hline 01308000 - Sampawams Creek at Babylon2 & 4.53 & 6.19 & 5.38 & 8.19 & 10.87 & 11.22 & 13.67 & 10.97 & 7.03 & 6.54 & 4.58 & 3.68 \\
\hline 01308500 - Carlls River at Babylon & 16.53 & 19.10 & 21.43 & 26.32 & 27.82 & 27.22 & 32.76 & 25.69 & 18.56 & 17.33 & 14.45 & 12.85 \\
\hline 01309000 - Santapogue Creek at Lindenhurst 3 & 1.16 & 1.79 & 2.26 & 3.17 & 4.01 & 3.97 & 5.47 & 3.69 & 1.91 & 1.63 & 1.16 & .72 \\
\hline 01309500 - Massapequa Creek at Massapequa & 4.43 & 6.40 & 6.53 & 8.79 & 10.32 & 9.80 & 12.86 & 9.62 & 6.28 & 5,38 & 4.00 & 3.10 \\
\hline 01310000 - Be11more Creek at Bellmore & 7.43 & 9.66 & 10.39 & 12.35 & 14.30 & 14.18 & 17.70 & 13.38 & 8.86 & 8.30 & 6.43 & 5.95 \\
\hline 01310500 - East Meadow Brook at Freeport4 & $4.83 *$ & $7.59 *$ & $7.80 *$ & 9.70 & 11.52 & 10.82 & 13.39 & 10.90 & 8,21 & 6.73 & 3.47 & 1.98 \\
\hline 01311000 - Pines Brook at Malverne & .20 & .39 & .56 & .88 & 1.08 & 1.14 & 1.41 & .94 & 40 & .17 & .03 & 0 \\
\hline 01311500 - Valley Stream at Valley Stream & 0 & .10 & .17 & .59 & .68 & .64 & 1.17 & .53 & .08 & .05 & 0 & 0 \\
\hline
\end{tabular}

* Monthly mean base flow calculated from wholly or partially estimated records.

1 Including diversion through hatchery.

2 Indeterninate effect on base flow caused by ground-water pumpage at well field one-quarter mile northwest of gage.

3 Base flow affected to unknown degree by ground-water pumpage at well field 2,400 ft north of gage.

4 Station inoperative from November 14, 1962 to December 16, 1963 as a result of stream relocation. Monthly mean base flow for October, November, and December 1963 based on estimated daily values. 
Water Year 1965

\begin{tabular}{|c|c|c|c|c|c|c|c|c|c|c|c|c|}
\hline Station & oct. & Nov. & Dec. & Jan. & Feb. & Mar. & Apr. & May & June & July & Aug. & Sept. \\
\hline 01302500 - Glen Cove Creek at Glen Cove 1 & 3.24 & 3.19 & 3.74 & 3.42 & 3.54 & 3.58 & 4.03 & 3.54 & 3.07 & 2.96 & 2.90 & 2.90 \\
\hline 01303000 - Mil1 Neck Creek at Mill Neck & 6.07 & 6.20 & 7.16 & 6.49 & 7.02 & 6.50 & 6.24 & 5.45 & 4.92 & 4.71 & 4.55 & 4.57 \\
\hline 01303500 - Cold Spring Brook at Cold Spring Harbor2 & 2.44 & 2.73 & 3.09 & 2.99 & 3.24 & 2.56 & 2.52 & 1.82 & 2.04 & 2.16 & 1.74 & 1.72 \\
\hline 01304000 - Nissequogue River near Smithtown & 32.37 & 30.52 & 37.82 & 35.76 & 39.1 .3 & 38.13 & 38.03 & 33.00 & 30.57 & 27.56 & 27.40 & 26.75 \\
\hline 01304500 - Peconic River at Riverhead & 20.31 & 17.25 & 27.71 & 27.35 & 34.04 & 35.24 & 32.20 & 27.24 & 20.87 & 18.02 & 22.37 & 15.87 \\
\hline 01305000 - Carmans River at Yaphank & 18.95 & 18.35 & 19.61 & 19.52 & 20.46 & 19.15 & 18.68 & 17.21 & 16.24 & 15.61 & 15.40 & 14.37 \\
\hline 01305500 - Swan River at East Patchogue & 9.95 & 9.79 & 10.13 & 10.69 & 12.13 & 11.97 & 11.55 & 11.00 & 9.75 & 9.27 & 9.48 & 9.23 \\
\hline 01306000 - Patchogue River at Patchogue & 17.00 & 15.45 & 18.60 & 18.16 & 20.34 & 20.16 & 19.1 .2 & 17.68 & 17.47 & 17.31 & 15.95 & 14.62 \\
\hline 01306500 - Connetquot River near Oakdale & 32.06 & $31.20 *$ & $35.35 *$ & 34.42 & 37.25 & 32.03 & 34.23 & 31.87 & 28.67 & 24.50 & $24.13^{*}$ & $22.33 *$ \\
\hline 01307000 - Champlin Creek at Islip & 3.51 & 3.75 & 5.90 & 6.04 & 7.37 & 6.84 & 6.56 & 5.93 & 4.72 & 3.76 & 3.34 & 3.21 \\
\hline 01307500 - Penataquit Creek at Bay Shore & 4.69 & 4.08 & 5.59 & 5.53 & 6.52 & 6.15 & 6.28 & 5.70 & 4.88 & 4.28 & 4.12 & 3.78 \\
\hline 01308000 - Sampawams Creek at Babylon 3 & 5.46 & 5.65 & 8.14 & 8.65 & 10.40 & 9.08 & 8.35 & 7.05 & 5.71 & 4.77 & 4.34 & 3.88 \\
\hline 01308500 - Carlls River at Babylon & 16.42 & 14.95 & 20.90 & 21.90 & 26.89 & 22.94 & 22.60 & 18.00 & 13.64 & 10.94 & 10.39 & 9.38 \\
\hline 01309000 - Santapogue Creek at Lindenhurst 4 & 1.01 & 1.07 & 2.35 & 2.82 & 3.69 & 2.97 & 3.14 & 2.37 & 1.19 & .708 & .761 & .671 \\
\hline 01309500 - Massapequa Creek at Massapequa & 4.86 & 4.29 & 6.13 & 6.40 & 8.18 & 7.46 & 7.80 & 5.66 & 3.55 & 2.89 & 2.93 & 2.19 \\
\hline 01310000 - Bellmore Creek at Bellmore & 6.47 & 6.01 & 7.00 & 6.33 & 10.34 & 9.11 & 7.53 & 5.73 & 4.00 & 2.45 & 2.12 & 1.92 \\
\hline 01310500 - East Meadow Brook at Freeport & 2.55 & 2.44 & $5.21 *$ & 6.58 & 8.93 & 8.03 & $7.65 *$ & $5.13 *$ & 3.04 & 1.35 & .82 & .347 \\
\hline 01311000 - Pines Brook at Malverne & 0 & .038 & .216 & $.261 *$ & .561 * & .543 & .566 & .352 & .076 & o & 0 & 0 \\
\hline 01311500 - Valley Stream at Valley Stream & 0 & 0 & .038 & .017 & .017 & .103 & .174 & .096 & 0 & o & o & 0 \\
\hline
\end{tabular}

* Monthly mean base flow calculated from wholly or partially estimated records.

1 Monthly mean base flow for Glen Cove Creek based on hydrograph from which unknown discharge has been separated,

2 Including diversion through hatchery.

3 Indeterminate effect on base flow caused by ground-water pumpage at well field one-quarter mile northwest of gage.

4 Base flow affected to unknown degree by ground-water pumpage at well field 2,400 ft north of gage. 
Table 2.--Monthly mean base flow for 19 continuousty gaged Long Island streams, water years $1960-75$ (continued)

Water Year 1966

\begin{tabular}{|c|c|c|c|c|c|c|c|c|c|c|c|c|}
\hline Station & Oct. & Nove & Dec. & Jan. & Feb. & Mar. & Apr. & May & June & July & Aug. & sept. \\
\hline 01302500 - Glen Cove Creek at Glen Cove & 2.84 & 2.93 & 3.09 & 3.19 & 3.65 & 3.49 & 3.43 & 3.49 & 3.32 & $3.19 *$ & $3.16 *$ & 3.01 \\
\hline 01303000 - Mi11 Neck Creek at Mil1 Neck & 5.00 & 5.38 & 5.79 & 5.88 & 6.18 & 6.04 & 4.98 & 5.12 & 4.45 & 3.93 & 4.28 & 4.51 \\
\hline 01303500 - Cold Spring Brook at Cold Spring Harborl & 1.45 & 1.68 & 1.95 & 1.82 & 1.83 & 1.67 & 1.23 & 1.22 & .99 & 1.17 & .74 & 1.49 \\
\hline 01304000 - Nissequogue River near Smithtown & 26.90 & 27.33 & 27.56 & 27.52 & 29.11 & 28.27 & 26.97 & 28.68 & 25.28 & 22.10 & 21.08 & 22.45 \\
\hline 01304500 - Peconic River at Riverhead & 15.50 & 14.60 & 14.44 & 14.34 & 18.11 & 21.55 & 16.72 & 18.37 & 19.62 & 12.94 & 11.33 & 10.70 \\
\hline 01305000 - Carmans River at Yaphank & 14.18 & 13.40 & 13.15 & 13.15 & 14.27 & 14.48 & 12.97 & 13.15 & 13.83 & 10.39 & 10.05 & 9.53 \\
\hline 01305500 - Swan River at East Patchogue & 8.29 & 7.49 & 8.22 & 8.40 & 9.09 & 9.42 & 8.73 & 8.76 & 9.31 & 7.78 & 7.53 & 7.87 \\
\hline 01306000 - Patchogue River at Patchogue & 14.08 & 13.87 & 13.07 & 14.34 & 16.50 & 16.57 & 14.92 & 13.39 & 16.60 & 12.13 & 12.39 & 12.36 \\
\hline 01306500 - Connetquot River near Oakdale & $22.46 *$ & $22.93 *$ & 23.78 & 26.05 & $28.59^{*}$ & 28.84 & 25.38 & $26.69 *$ & $25.98 *$ & $19.36 *$ & 18.72 & 20.56 \\
\hline 01307000 - Champlin Creek at Islip & 3.25 & 3.37 & 3.27 & 2.72 & 4.32 & 4.18 & 3.40 & 5.06 & 4.79 & 3.39 & 2.99 & 2.62 \\
\hline 01307500 - Penataquit Creek at Bay Shore & 3.07 & 2.86 & 3.27 & 3.40 & 4.29 & 4.49 & 3,51 & 4.47 & 4.71 & 3.60 & 2.97 & 3.36 \\
\hline 01308000 - Sampawams Creek at Babylon2 & 4.55 & 4.22 & 4.06 & 5.92 & 6.98 & 7.18 & 5.55 & 6.94 & $5.81 *$ & 3.28 & $3.3 .3 *$ & 4.80 \\
\hline 01308500 - Car11s River at Babylon & 10.01 & 10.66 & 11.64 & 12.25 & 16.93 & 17.65 & 12.60 & 17.78 & 14.59 & 8.85 & 8.21 & 10.76 \\
\hline 01309000 - Santapogue Creek at Lindenhurst 3 & .68 & .76 & .80 & .98 & 1.53 & 1.94 & 1.48 & 2.28 & 1.57 & .58 & .57 & .96 \\
\hline 01309500 - Massapequa Creek at Massapequa & 2.12 & 1.84 & 1.88 & 2.27 & 3.56 & 3.44 & 2.62 & 3.97 & 3.31 & 1.85 & 1.52 & 2.20 \\
\hline 01310000 - Bellmore Creek at Bellmore & 2.03 & 2.01 & 1.95 & 3.26 & $2.33 *$ & 3.65 & 3.49 & 4.85 & $4.66 *$ & 2.36 & 1.59 & 2.59 \\
\hline 01310500 - East Meadow Brook at Freeport & .40 & .57 & .80 & 1.11 & 1.40 & 1.71 & 1.34 & 2.00 & I. 28 & .18 & .12 & .49 \\
\hline 01311000 - Pines Brook at Malverne & 0 & 0 & 0 & 0 & 0 & 0 & 0 & 0 & 0 & 0 & 0 & o \\
\hline 01311500 - Valley Stream at Valley Stream & 0 & 0 & 0 & 0 & 0 & 0 & 0 & 0 & 0 & 0 & 0 & 0 \\
\hline
\end{tabular}

* Monthly mean base flow calculated from wholly or partially estimated records.

1 Including diversion through hatchery.

2 Indeterminate effect on base flow caused by ground-water pumpage at well field one-quarter mile northwest of gage.

3 Base flow affected to unknown degree by ground-water pumpage at well field $2,400 \mathrm{ft}$ north of gage. 
Water Year 1967

\begin{tabular}{|c|c|c|c|c|c|c|c|c|c|c|c|c|c|}
\hline & Station & oct. & Nov. & Dec. & Jan. & Feb. & Mar. & Apr. & May & June & JuIy & Aug : & Sept. \\
\hline 01302500 & - Glen Cove Creek at Glen Cove & 2.95 & 2.95 & 2.67 & 2.93 & 2.80 & 3.59 & 2.73 & 2.98 & 2.68 & 2.85 & $2.87 *$ & $2.43 *$ \\
\hline 01303000 & - Mill Neck Creek at Mill Neck & 4.38 & 5.06 & 4.78 & 4.69 & 5.39 & 6.42 & 5.27 & 5.05 & 4.37 & 5.07 & 5.23 & 4.62 \\
\hline 01303500 & - Cold Spring Brook at Cold Spring Harbor 1 & 1.27 & 1.09 & 1.11 & 1.23 & 1.09 & 1.37 & 1.52 & 1.70 & $.97^{*}$ & .78 & .89 & .77 \\
\hline 01304000 & - Nissequogue River near Smithtown & 22.69 & 23.67 & 23.26 & 22.92 & 22.75 & 28.31 & 29.98 & 32.85 & 31.32 & 30.45 & 29.53 & 28.05 \\
\hline 01304500 & - Peconic River at Riverhead & 12.19 & 13.08 & 12.56 & 14.84 & 16.27 & 24.47 & 28.78 & 31.58 & 32.05 & 30.82 & 26.61 & 21.60 \\
\hline 01305000 & - Carmans River at Yaphank & 10.47 & 10.28 & 9.13 & 9.25 & $10.28 *$ & $13.61 *$ & 14.40 & 15.29 & 14.83 & 14.22 & 14.71 & 14.52 \\
\hline 01305500 & - Swan River at East Patchogue & 8.13 & 7.77 & 7.44 & 7.58 & 7.86 & 9.95 & 10.72 & 11.56 & 10.66 & 10.95 & 11.19 & 9.46 \\
\hline 01306000 & - Patchogue River at Patchogue & 13.98 & 13.29 & 13.03 & 13.28 & 12.35 & 17.11 & 18.81 & 19.13 & 18.38 & 19.05 & 18.26 & 17.53 \\
\hline 01306500 & - Connetquot River near Oakdale & 20.92 & 21.92 & 20.71 & 23.29 & 22.89 & 31.22 & 31.78 & 32.79 & 32.43 & 33.73 & 30.40 & 27.45 \\
\hline 01307000 & - Champlin Creek at Islip & 3.05 & 3.60 & 3.29 & 3.73 & 4.04 & 6.30 & 6.90 & 8.26 & 6.89 & 6.75 & 5.65 & 5.27 \\
\hline 01307500 & - Penataquit Creek at Bay Shore & 3.58 & 4.38 & 4.02 & 3.53 & 3.84 & 6.50 & 5.86 & 7.08 & 6.73 & 6.09 & 6.05 & 5.36 \\
\hline 01308000 & - Sampawams Creek at Babylon2 & $5.65 *$ & 5.20 & $5.09 *$ & $5.72 *$ & $6.07 *$ & $8.76 *$ & $8.40 *$ & $9.83^{*}$ & $8.40 *$ & $8.58 *$ & $9.29 *$ & $7.15 *$ \\
\hline 01308500 & - Carlls River at Babylon & 12.98 & 13.94 & 12.71 & $13.90 *$ & 14.19 & 21.58 & 20.82 & 23.85 & 19.81 & 23.24 & 20.89 & 17.60 \\
\hline 01309000 & - Santapogue Creek at Lindenhurst 3 & 1.30 & 1.37 & 1.13 & 1.54 & 1.68 & 3.30 & 3.25 & 4.03 & $3.01 *$ & $3.1 .1 *$ & 3.64 & 2.45 \\
\hline 01309500 & - Massapequa Creek at Massapequa & 3.60 & 3.52 & 3.62 & 3.89 & 3.83 & 6.17 & 6.38 & 7.30 & 5.06 & 5.68 & 6.00 & 3.97 \\
\hline 01310000 & - Be11more Creek at Bellmore & 3,72 & 4.16 & 3.19 & 4.34 & 3.79 & 8.22 & 8.53 & 8.60 & 6.14 & 6.43 & 7.29 & 5.84 \\
\hline 01310500 & - East Meadow Brook at Freeport & 1.22 & 1.44 & 1.10 & 1.50 & 1.34 & 2.58 & 2.46 & 3.42 & 2.65 & 4.78 & 5.76 & 3.17 \\
\hline 01311000 & - Pines Brook at Malverne & 0 & 0 & 0 & 0 & $.008^{*}$ & $.277 *$ & $.355^{\star}$ & $.426 \star$ & .129 & .067 & $.102 *$ & .023 \\
\hline 01311500 & - Valley Stream at Valley Stream & 0 & 0 & 0 & 0 & 0 & .057 & .331 & .576 & .244 & .185 & .129 & 0 \\
\hline
\end{tabular}

* Monthly mean base flow calculated from wholly or partially estimated records.

1 Including diversion through hatchery.

2 Gage inoperative from November 29, 1966 to September 30, 1967. Monthly mean base flow calculated as a percentage of estimated monthly mean discharge for this period. Indeterminate effect on base flow caused by ground-water pumpage at well field one-quarter mile northwest of gage.

3 Base flow affected to unknown degree by ground-water pumpage at well field 2,400 $\mathrm{ft}$ north of gage. 
Table 2.-Monthty mean base flow for 19 continuously gaged Long Istand streams, water years 1960-75 (continued)

Water Year 1968

\begin{tabular}{|c|c|c|c|c|c|c|c|c|c|c|c|c|c|}
\hline & Station & oct. & Nov. & Dec. & $\tan$ & Feb. & Max. & Apr. & May & June & JuIy & Rug. & Sept. \\
\hline $01302500-$ & - Glen Cove Creek at GIen Cove & 2.41 & 2.67 & 3.10 & 2.89 & 2.75 & 3.49 & 2.86 & 2.84 & 3.70 & 3.05 & 3.29 & 3.22 \\
\hline $01303000-$ & - Mi1l Neck Creek at Mill Neck & 4.90 & 5.26 & 5.81 & 5.57 & 5.38 & 6.23 & 5.19 & $5.21 *$ & 6.17 & 5.24 & 5.07 & 5.23 \\
\hline $01303500-$ & - Cold Spring Brook at Cold Spring Harborl & $.60 *$ & .87 & 1.31 & 1.60 & 1.54 & 1.16 & 1.08 & 1.33 & 1.37 & 1.06 & 1.18 & 1.16 \\
\hline $01304000-$ & - Nissequogue River near Smithtown & 29.79 & 29.70 & 32.79 & 32.94 & 33.50 & 38.63 & 35.03 & 33.18 & 33.90 & 28.53 & 28.92 & 26.85 \\
\hline 01304500 & - Peconic River at Riverhead & 19.24 & 20.40 & 24.50 & 28.44 & 28.50 & $36.63^{*}$ & 33.57 & 33.94 & 32.17 & 21.48 & 17.81 & 15.18 \\
\hline $01305000-$ & - Carmans River at Yaphank & 14.60 & 14.18 & 15.01 & 16.52 & 16.42 & 18.69 & 18.27 & 17.98 & 18.32 & 17.58 & 15.89 & 15.73 \\
\hline 01305500 & - Swan River at East Patchogue & 9.20 & 9.07 & 9.39 & 9.89 & 9.42 & 10.61 & 11.11 & 10.33 & 10.63 & 8.58 & 8.68 & 8.33 \\
\hline $01306000-$ & - Patchogue River at Patchogue & 16.38 & 16.24 & 16.73 & 17.13 & 17.71 & 19.65 & 19.57 & 18.81 & 19.20 & 18.08 & 17,11 & 14.75 \\
\hline 01306500 & - Connetquot River near Oakdale & 25.56 & 26.68 & 32.00 & 34.23 & 31.36 & 36.90 & 33.58 & 32.08 & 36,72 & 29.81 & 26.37 & 26.78 \\
\hline $01307000-$ & - Champlin Creek at Islip & 4.35 & $3.72 *$ & $5.53^{*}$ & 5.99 & 5.02 & 7.13 & 6.51 & 4.94 & 5.94 & 5.11 & 5.30 & 5.08 \\
\hline 01307500 & - Penataquit Creek at Bay Shore & 4.89 & 4.59 & 5.53 & 5.66 & 4.87 & 6.05 & 5.07 & 4.62 & 5.91 & 5.02 & 5.12 & 4.30 \\
\hline 01308000 & - Sampawams Creek at Babylon2 & $5.57 *$ & $5.77 *$ & $6.64^{k}$ & 7.60 & 6.49 & $7.92 *$ & 7.11 & 6.47 & $7.1 .7 *$ & 5.21 & 4.40 & 4.57 \\
\hline $01308500-$ & - Car1ls River at Babylon & 15.77 & 15.39 & 20.19 & 20.89 & 17.95 & 22.36 & 18.52 & 16.08 & 18.60 & 12.92 & 11.36 & 11.62 \\
\hline 01309000 & - Santapogue creek at Lindenburst3 & 1.95 & $1.87^{*}$ & $2.65 *$ & 2.95 & 2.18 & 3.43 & 2.08 & 1.50 & 2.48 & 1.36 & 1.02 & .88 \\
\hline 01309500 & - Massapequa Creek at Massapequa & 4.20 & 6.46 & 6.74 & 6.61 & 5.89 & 7.11 & 5.66 & 5.59 & 6.24 & 3.89 & 3.20 & 3.43 \\
\hline 01310000 & - Bellnore Creek at Bellmore & 5.15 & 5.09 & 7.38 & 7.42 & 7.04 & 8.76 & 5.58 & 6.13 & 8.87 & 4.81 & 3.76 & 4.37 \\
\hline 01310500 & - East Meadow Brook at Freeport & 2.54 & 3.45 & $5.43 *$ & 5,40 & 4.97 & 6.69 & 5.75 & 4.73 & 6.24 & 3.04 & 3.32 & 3.52 \\
\hline 01311000 & - Pines Brook at Malverne & .017 & .05 & .19 & $23^{*}$ & $.21 *$ & .38 & .25 & .13 & .14 & .008 & o & 0 \\
\hline 01312500 & - Valley Stream at Valley Stream & 0 & 0 & 0 & 0 & 0 & 0 & 0 & 0 & 0 & 0 & 0 & 0 \\
\hline
\end{tabular}

* Monthly mean base flow calculated from wholly or partially estimated records.

1 Tncluding diverston through hatchery.

2 No gage helght records from october 1 to Decenber 5, 1967. Base flow calculated from estimated daily mean discharge records.

Indeterminate effect on base flow caused by ground-water pumpage at well fleld one-quarter mile northwest of gage.

3 Base flow affected to unknown degree by ground-water pumpage at well field 2,400 ft north of gage. 
Water Year 1969

\begin{tabular}{|c|c|c|c|c|c|c|c|c|c|c|c|c|c|}
\hline & Station & Oct. & Nov. & Dec. & $\operatorname{Jan}$ & Feb. & Mar. & Apr & May & June & July & Aug. & sept. \\
\hline 01302500 & - Glen Cove Creek at Glen Cove & 3.26 & 3.55 & $3.32 *$ & $2.88^{*}$ & 3.12 & 3.83 & 3.77 & 3.15 & 2.96 & 3.40 & 3.33 & 2.99 \\
\hline 01303000 & - Mil1 Neck Creek at Mil1 Neck. & 5.07 & 6.21 & 6.18 & 5.71 & 3.98 & 5.23 & 5.92 & 5.65 & 5.24 & 5.68 & 5.43 & 5.82 \\
\hline 01303500 & - Cold Spring Brook at Cold Spring Harborl & .86 & $1.27 *$ & 1.70 & 1.78 & 1.67 & 1.76 & 2.03 & 1.76 & 1.79 & 1.39 & 1.58 & 1.95 \\
\hline 01304000 & - Nissequogue River near Smithtown & 25.21 & 28.98 & 32.18 & 30.23 & 30.21 & $31.18 *$ & 34.40 & $33.47 *$ & $29.13 *$ & 29.02 & 30.61 & 29.95 \\
\hline 01304500 & - Peconic River at Riverhead & 13.90 & 22.18 & 26.27 & 26.35 & $24.46 *$ & $27.16 *$ & 32.20 & 30.35 & 20.23 & 18.52 & 29.61 & 21.88 \\
\hline 01305000 & - Carmans River at Yaphank & 14.65 & 15.51 & 16.20 & 16.01 & 15.01 & 15.23 & 16.54 & 17.31 & 16.15 & 13.94 & $15.78 *$ & $14.94 *$ \\
\hline 01305500 & - Swan River at East Patchogue & 8.04 & 8.71 & 9.24 & 9.29 & 9.33 & $9.22 *$ & $9.79 *$ & 10.49 & 9.35 & 9.42 & 10.06 & 8.93 \\
\hline 01306000 & - Patchogue River at Patchogue & 13.21 & 14.39 & 16.23 & 15.23 & 15.43 & 15.06 & 17.60 & 17.32 & 17.12 & 15.69 & 16.13 & 15.98 \\
\hline 01306500 & - Connetquot River near Oakdale & 24.52 & 29.17 & $33.73 *$ & 30.35 & $30.11 *$ & 30.47 & $30.80 *$ & 28.06 & 26.35 & 25.03 & 29.58 & $27.28 *$ \\
\hline 01307000 & - Champlin Creek at Islip & 3.33 & 4.44 & 6.00 & 5.13 & 5.23 & 5.28 & 5.91 & 5.87 & 4.66 & 4.32 & 6.52 & 6.01 \\
\hline 01307500 & - Penataquit Creek at Bay Shore & 3.72 & 4.59 & 6.00 & 5.38 & 5.54 & $5.55 *$ & $6.45 *$ & 8.24 & 5.49 & 5.22 & 6.67 & 7.97 \\
\hline 01308000 & - Sampawams Creek at Babylon2 & $3.99 *$ & $5.26 *$ & 6.43 & 5.48 & 5.75 & 6.93 & $7.20^{*}$ & 9.63 & $5.72 *$ & $5.51^{*}$ & $6.99 *$ & $4.67^{*}$ \\
\hline 01308500 & - Car1ls River at Babylon & 11.10 & 16.10 & 21,00 & 17.43 & 18.11 & $20.65 *$ & 21.28 & 18.55 & 14.54 & 16.32 & 19.23 & 16.88 \\
\hline 01309000 & - Santapogue Creek at Lindenhurst 3 & .67 & $1.50^{\star}$ & 2.49 & 1.85 & 2.02 & 2.28 & 2.63 & 2.28 & 1.23 & 1.41 & 2.35 & 1.80 \\
\hline 01309500 & - Massapequa Creek at Massapequa & 3.78 & 5.39 & 7.15 & 6.23 & 6.35 & 7.19 & 7.07 & 6.72 & $4.97 *$ & $4.56 *$ & 4.84 & 4.53 \\
\hline 01310000 & - Bellmore Creek at Bellmore & 3.57 & 4.95 & 7.38 & 5.48 & 6.26 & 6.83 & 8.89 & 7.96 & 5.75 & 5.05 & 4.92 & 4.83 \\
\hline 01310500 & - East Meadow Brook at Freeport & 2.37 & 4.03 & 5.66 & 3.86 & 5.00 & $7.4 I$ & 20.59 & 11.87 & 12.78 & 10.00 & 9.33 & 10.88 \\
\hline 01311000 & - Pines Brook at Malverne & 0 & .036 & .176 & $.152 *$ & $.181 *$ & $.30 *$ & $.436 *$ & .252 & $.011 *$ & .018 & $.035 *$ & 0 \\
\hline 01311500 & - Valley Stream at Valley Stream & 0 & 0 & .108 & .096 & .011 & .169 & .445 & .256 & .122 & $.083 *$ & .343 & .182 \\
\hline
\end{tabular}

* Monthly mean base flow calculated from wholly or partially estimated records.

1 Including diversion through hatchery.

2 Indeterminate effect on base flow caused by ground-water pumpage at well field one-quarter mile northwest of gage.

3 Base flow affected to unknown degree by ground-water pumpage at well field $2,400 \mathrm{ft}$ north of gage. 
Table 2.--Monthly mean base flow for 19 continuously gaged Long Istand streams, water years 1960-75 (continued)

Water Year 1970

\begin{tabular}{|c|c|c|c|c|c|c|c|c|c|c|c|c|}
\hline Station & Oct. & Nov. & Dec. & Jan. & Feb. & Mar. & Apr. & May & June & JuIY & Aug, & sept. \\
\hline 01302500 - Glen Cove Creek at Glen Cove & 2.53 & 2.71 & 3.11 & 2.95 & 3.54 & 3.11 & 3.44 & 3.35 & 3.15 & 2.87 & 2.78 & 2.77 \\
\hline 01303000 - Mil1 Neck Creek at Mil1 Neck & $5.54 *$ & 6.07 & 6.39 & $6.24 *$ & 7.07 & 7.01 & 6.95 & 6.31 & 5.88 & 5.52 & 5.27 & 5.53 \\
\hline 01303500 - Cold Spring Brook at Cold Spring Harbor 1 & 1.99 & 1.55 & $1.88 *$ & $2.24 *$ & 3.03 & 3.22 & 3.46 & 2.38 & 2.38 & 2.52 & $2.78 *$ & $2.21 *$ \\
\hline 01304000 - Nissequogue River near Smithtown & $33.06 *$ & 35.13 & 38.77 & 38.03 & 42.46 & 41.26 & 46.90 & 43.13 & 39.50 & 33.65 & 33.13 & 31.83 \\
\hline 01304500 - Peconic River at Riverhead & 20.02 & 25.30 & 28.87 & 37.48 & 43.46 & 36.68 & 54.27 & 48.90 & 35.17 * & 29.50 & 26.76 & $18.60 *$ \\
\hline 01305000 - Carmans River at Yaphank & 15.29 & 25.60 & 16.90 & $19.10 *$ & 20.34 & 19.15 & 24.37 & 22.39 & 20.30 & 19.90 & $20.71 *$ & 18.93 \\
\hline 01305500 - Swan River at East Patchogue & 9.13 & 9.83 & 9.91 & 10.09 & 11.20 & 11.37 & 14.15 & 13.38 & 11.36 & 9.94 & 9.90 & 8.96 \\
\hline 01306000 - Patchogue River at Patchogue2 & - & - & - & - & - & - & - & - & - & - & - & - \\
\hline 01306500 - Connetquot River near Oakdale & $27.81 *$ & 30.57 & 34.15 & $35.42 *$ & 37.55 & $35.50 *$ & 42.90 & 37.90 & 35.25 & 32.82 & 30.84 & 29.08 \\
\hline 01307000 - Champlin Creek at Islip 2 & - & - & - & - & - & - & - & - & - & - & - & - \\
\hline 01307500 - Penataquit Creek at Bay Shore & 5.88 & 4.99 & 5.59 & 6.11 & 6.70 & 7.22 & 8.82 & 6.74 & 5.80 & 4.90 & 4.52 & 4.30 \\
\hline 01308000 - Sampawams Creek at Babylon 3 & $6.17 *$ & 6.90 & 9.16 & 10.77 & 11.48 & 10.33 & 14.97 & 11.04 & 8.04 * & $6.10 *$ & $5.06 *$ & $5.34 *$ \\
\hline 01308500 - Carlis River at Babylon & 15.65 & 17.40 & 21.94 & 23.68 & 26.75 & 23.94 & 30.50 & 23.42 & 19.87 & 15.43 * & 13.42 & 13.70 \\
\hline 01309000 - Santapogue Creek at Lindenhurst 2 & - & - & - & - & - & - & - & - & - & - & - & - \\
\hline 01309500 - Massapequa Creek at Massapequa 4 & 4.75 & 9.13 & 10.71 & 9.66 & 13.25 & 9.12 & 9.53 & 8.19 & 6.52 & 4.42 & 3.66 & 3.48 \\
\hline 01310000 - Bellmore Creek at Bellmore & $2.99 *$ & 4.60 & 6.57 & 6.71 & 9.29 & 8.90 & $11.28 *$ & 7.15 & 6.10 & 4.94 & 2.27 & 2.46 \\
\hline 01310500 - East Meadow Brook at Freeport & 7.20 & 7.08 & 7.03 & 8.75 & 9.78 & 9.37 & 11.28 & 8.66 & 6.71 & 3.76 & 2.56 & 1.57 \\
\hline 01311000 - Pines Brook at Malverne5 & 0 & .024 & .14 & $.193 *$ & .47 & - & - & - & - & - & - & - \\
\hline 01311500 - Valley Stream at Valley Stream & .008 & 0 & .31 & .46 & .41 & .40 & .87 & .61 & .14 & 0 & 0 & 0 \\
\hline
\end{tabular}

* Monthly mean base flow calculated from wholly or partially estimated records.

1 Including diversion through hatchery.

2 Patchogue River, Champlin Creek, and Santapogue Creek discontinued as continuous gaging stations.

3 Indeterminate effect on base flow caused by ground-water pumpage at well field one-quarter mile northwest of gage.

4 Base flow augmented to unknown degree by dewatering, associated with sewer construction, throughout much of the year,

5 No discharge record from March 1970 through September 1970. 
Water Year 1971

\begin{tabular}{|c|c|c|c|c|c|c|c|c|c|c|c|c|}
\hline Station & oct. & Nov. & Dec. & Jan. & Feb。 & Mar. & Apr. & May & June & JuIy & Aug. & sept. \\
\hline 01302500 - G1en Cove Creek at Glen Cove & 2.91 & 3.04 & 2.88 & 2.61 & 3.19 & 3.56 & 2.91 & 3.05 & 2.80 & 2.68 & 2.85 & 2.95 \\
\hline 01303000 - Mil1 Neck Creek at Mi11 Neck & 5.29 & 6.19 & 6.21 & 5.61 & 6.28 & 6.12 & 5.39 & 5.87 & 5.59 & 5.41 & 5.05 & 5.25 \\
\hline 01303500 - Cold Spring Brook at Cold Spring Harborl & 2.76 & 3.08 & 2.94 & 3.40 & 3.60 & 3.40 & 2.80 & 2.81 & 2.33 & 2.05 & 2.36 & 2.51 \\
\hline 01304000 - Nissequogue River near Smithtown & 30.89 & 35.87 & 35.90 & 35.97 & 39.50 & 43.02 & 39.17 & 36.79 & 32.07 & 29.77 & 29.50 & 29.92 \\
\hline 01304500 - Peconic River at Riverhead & 19.26 & 25.65 & 25.53 & 27.00 & 33.93 & 45.95 & 35.98 & 33.79 & 25.63 & 19.00 & 17.94 & 16.72 \\
\hline 01305000 - Carmans River at Yaphank & 17.11 & 17.69 & 16.26 & 16.23 & 18.11 & 20.59 & 19.53 & 18.41 & 14.17 & 14.94 & 14.35 & 13.45 \\
\hline 01305500 - Swan River at East Patchogue & 8.92 & 9.33 & 8.69 & 9.30 & 9.77 & 11.80 & 11.06 & 10.19 & 8.60 & 8.11 & 8.05 & 8.32 \\
\hline 01306000 - Patchogue River at Patchogue2 & - & - & - & - & - & - & - & - & - & - & - & - \\
\hline 01306500 - Connetquot River near Oakdale & 26.24 & 26.98 & 29.65 & 29.61 & 32.16 & 36.85 & 35.93 & 34.84 & 28.63 & 23.56 & 25.79 & 26.10 \\
\hline 01307000 - Champlin Creek at Is1ip2 & - & - & - & - & - & - & - & - & - & - & - & - \\
\hline 01307500 - Penataquit Creek at Bay Shore & 3.94 & 4.50 & $4.85 *$ & 4.71 & 4.87 & 6.86 & 6.23 & 6.05 & 6.16 & 4.30 & $4.5 I^{*}$ & 4.77 \\
\hline 01308000 - Sampawams Creek at Babylon 3 & 4.66 & 5.23 & 5.58 & 6.56 & 7.32 & 9.05 & 8.94 & 8.09 & 6.59 & 5.17 & 4.35 & 4.60 \\
\hline 01308500 - Car11s River at Babylon & 12.41 & 14.66 & 15.05 & 15.68 & 19.64 & 23.79 & 20.08 & 18.60 & $13.84 *$ & $10.64 *$ & $11.14^{*}$ & $13.78 *$ \\
\hline 01309000 - Santapogue Creek at Lindenhurst2 & - & - & - & - & - & - & - & - & - & - & - & - \\
\hline 01309500 - Massapequa Creek at Massapequa & 3.64 & 4.56 & 4.77 & 5.05 & 6.11 & 7.43 & 7.10 & 6.19 & 4.28 & 3.51 & 3.20 & 3.22 \\
\hline 01310000 - Bellmore Creek at Bel1more & 3.15 & 4.09 & 4.75 & 5.20 & 6.54 & 8.20 & 8.09 & 7.11 & 4.14 & 3.14 & 2.27 & 3.03 \\
\hline 01310500 - East Meadow Brook at Freeport & 1. .38 & 2.03 & 2.27 & 3.14 & 5.26 & 6.13 & 5.49 & 5.41 & 3.55 & 1.61 & .71 & 1.27 \\
\hline 01311000 - Pines Brook at Malverne & 0 & 0 & 0 & 0 & 0 & .04 & .05 & .001 & 0 & 0 & 0 & 0 \\
\hline 01311500 - Valley Stream at Valley Stream & 0 & 0 & 0 & 0 & 0 & .05 & .27 & .18 & 0 & 0 & 0 & 0 \\
\hline
\end{tabular}

* Monthly mean base flow calculated from wholly or partially estimated records.

1 Including diversion through hatchery.

2 Patchogue River, Champlin Creek, and Santipogue Creek discontinued as continuous gaging stations.

3 Indeterminate effect on base flow caused by ground-water pumpage at well field one-quarter mile northwest of gage. 
Table 2.--Monthly mean base flow for 19 continuously gaged Long Istand streams, water years $1960-75$ (continued)

Water Year 1972

\begin{tabular}{|c|c|c|c|c|c|c|c|c|c|c|c|c|}
\hline Station & oct. & Nov。 & Dec. & Jan. & Feb. & Mar。 & Apr. & May & June & July & Aug。 & Sept. \\
\hline 01302500 - Glen Cove Creek at Glen Cove & 2.86 & 3.07 & 3.09 & 3.10 & 3.49 & 3.97 & 3.31 & 3.53 & 3.93 & 3.54 & 3.06 & 3.30 \\
\hline 01303000 - Mil1 Neck Creek at Mill Neck & 5.45 & 5.94 & 6.15 & 6.30 & 6.96 & 7.66 & 7.32 & 7.62 & 7.87 & 6.77 & 6.26 & 6.33 \\
\hline 01303500 - Cold Spring Brook at Cold Spring Harborl & 2.34 & 2.14 & $2.65 *$ & $2.39 *$ & 2.75 & 2.84 & 2.54 & 2.92 & 2.95 & 2.79 & 2.23 & 2.67 \\
\hline 01304000 - Nissequogue River near Smithtown & 29.66 & 30.77 & 35.35 & 33.65 & 35.76 & 39.87 & 38.85 & 38.08 & 37.10 & 34.44 & 31.31 & 31.72 \\
\hline 01304500 - Peconic River at Riverhead & 15.48 & 15.57 & 24.02 & 22.48 & 26.97 & 42.35 & 39.93 & 47.65 & 49.30 & 48.77 & 29.74 & 25.52 \\
\hline 01305000 - Carmans River at Xaphank & 12.77 & 12.90 & 14.52 & 13.85 & 14.98 & 18.56 & 19.37 & 20.82 & 21.88 & $20 \cdot 34$ & 19.39 & 18.67 \\
\hline 01305500 - Swan River at East Patchogue & 8.48 & 8.41 & 10.14 & 10.37 & 9.85 & 10.95 & 11.19 & 12.26 & 13.13 & 12.10 & 10.19 & 9.37 \\
\hline 01306000 - Patchogue River at Patchogue2 & - & - & - & - & - & - & - & - & - & - & - & - \\
\hline 01306500 - Connetquot River near Oakdale & 22.65 & 25.87 & 33.02 & $30.10 *$ & $32.00 *$ & 37.10 & 35.20 & 36.48 & 37.30 & 33.68 & 29.39 & 26.33 \\
\hline 01307000 - Champlin Creek at Islip2 & - & - & - & - & - & - & - & - & - & - & - & - \\
\hline 01307500 - Penataquit Creek at Bay Shore & 4.25 & 5.07 & 6.07 & 4.91 & 5.80 & 6.95 & 5.62 & 9.73 & 7.16 & 5.45 & 5.17 & 3.80 \\
\hline 01308000 - Sampawams Creek at Babylon 3 & 4.83 & 5.36 & 7.84 & 7.43 & 8.55 & 11.07 & 10.60 & 11.21 & 11.49 & 9.98 & 6.41 & 5.54 \\
\hline 01308500 - Car11s River at Babylon & 13.87 & 14.70 & 21.73 & 19.69 & 23.05 & 26.76 & 23.43 & 26.11 & 26.43 & 21.82 & $14.08 *$ & 11.67 \\
\hline 01309000 - Santapogue Creek at Lindenhurst 2 & - & - & - & - & - & - & - & - & - & - & - & - \\
\hline 01309500 - Massapequa Creek at Massapequa & 3.56 & 4.09 & 6.51 & 5.84 & 7.46 & 8.66 & 9.05 & 9.68 & $10.08 *$ & 9.12 & 5.56 & 4.39 \\
\hline 01310000 - Bellmore Creek at Bellmore & 3.24 & 4.31 & 5.57 & 9.08 & 15.87 & 14.26 & 12.73 & 11.50 & 14.51 & 9.00 & 5.25 & 4.13 \\
\hline 01310500 - East Meadow Brook at Freeport & 1.68 & 2.15 & 3.55 & 3.86 & 4.65 & 7.56 & 7.57 & 7.92 & 8.15 & 6.73 & 2.73 & 1.89 \\
\hline 01311000 - Pines Brook at Malverne & 0 & 0 & 0 & .067 & .185 & .21 & .29 & .33 & .33 & .21 & .004 & 0 \\
\hline 01311500 - Valley Stream at Valley Stream & 0 & 0 & 0 & 0 & 0 & .067 & .059 & .21 & .182 & .098 & 0 & 0 \\
\hline
\end{tabular}

* Monthly mean base flow calculated from wholly or partially estimated records.

1 Including diversion through hatchery.

2 Patchogue River, Champlin Creek, and Santapogue Creek discontinued as continuous gaging stations.

3 Indeterminate effect on base flow caused by ground-water pumpage at well field one-quarter mile northwest of gage. 
Water Year 1973

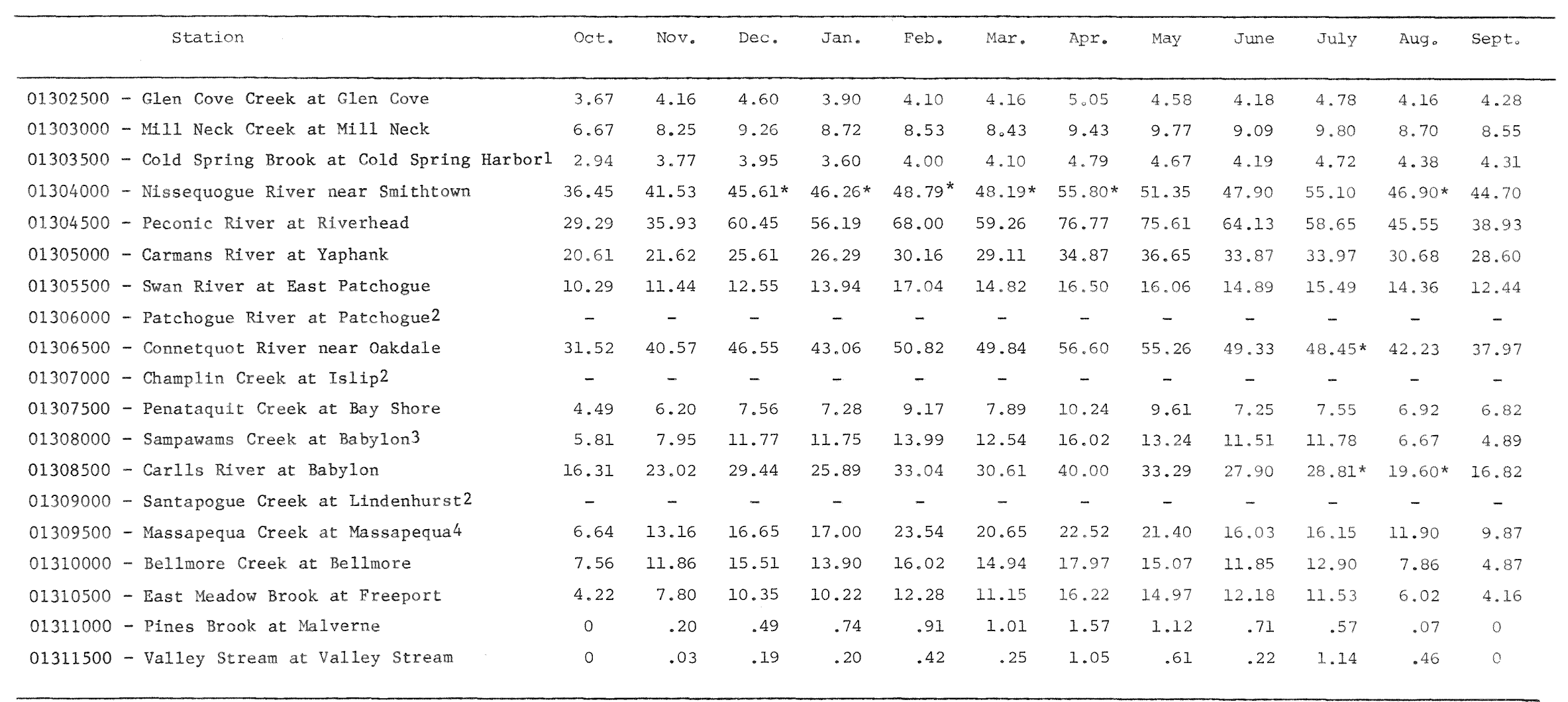

* Monthly mean base flow calculated from wholly or partially estimated records.

1 Including diversion through hatchery.

2 Patchogue River, Champlin Creek, and Santapogue Creek discontinued as continuous gaging stations.

3 Indeterminate effect on base flow caused by ground-water pumpage at well field one-quarter mile northwest of gage.

4 Base flow augmented to unknown degree by dewatering, associated with sewer construction, throughout much of the year. 
Table 2.-Monthly mean base flow for 19 continuously gaged Long Island streams, water years $1960-75$ (continued)

Water Year 1974

\begin{tabular}{|c|c|c|c|c|c|c|c|c|c|c|c|c|}
\hline Station & oct. & Nov. & Dec. & $\operatorname{Jan}$ & Feb. & Mar. & Apr & May & June & July & Aug。 & sept. \\
\hline 01302500 - Glen Cove Creek at Glen Cove & 4.06 & 4.14 & 5.03 & 5.00 & 4.51 & 4.90 & 5.71 & 4.65 & 4.71 & 4.03 & 4.49 & 4.64 \\
\hline 01303000 - Mi11 Neck Creek at Mi11 Neck & 8.97 & 9.73 & 10.33 & 9.76 & 9.39 & 9.07 & 9.46 & 9.14 & 8.66 & 7.58 & 7.46 & 8.78 \\
\hline 01303500 - Cold Spring Brook at Cold Spring Harbor1 & 4.53 & 5.10 & 5.37 & 4.79 & 4.80 & 4.77 & 5.42 & 5.02 & 5.16 & 5.15 & 4.23 & 4.06 \\
\hline 01304000 - Nissequogue River near Smithtown & 41.42 & 42.07 & 47.39 & 49.81 & 49.50 & 48.94 & 51.00 & 46.55 & 41.00 & 33.52 & 31.84 & 38.33 \\
\hline 01304500 - Peconic River at Riverhead & 30.13 & 30.30 & $44.00 *$ & 61.94 & 57.07 & 55.42 & 65.57 & 55.81 & 46.67 & $26.94 *$ & $22.39 *$ & $25.50 *$ \\
\hline 01305000 - Carmans River at Yaphank & 25.98 & 25.42 & 27.42 & 29.68 & 31.00 & 30.81 & 32.73 & 30.76 & 28.10 & 25.26 & 23.87 & 23.28 \\
\hline 01305500 - Swan River at East Patchogue & 11.50 & 10.32 & 12.35 & 13.05 & 13.08 & 12.85 & 14.28 & 13.40 & 12.57 & 10.49 & 9.75 & 10.97 \\
\hline 01306000 - Patchogue River at Patchogue & 17.68 & 16.65 & 19.63 & 21.42 & 20.71 & 22.73 & 24.47 & 23.69 & 19.03 & 17.25 & 15.42 & 17.17 \\
\hline 01306500 - Connetquot River near Oakdale & 35.48 & 35.33 & 41.48 & 43.55 & 41.93 & 41.87 & 45.70 & 39.29 & 38.07 & 31.29 & 26.45 & 28.70 \\
\hline 01307000 - Champlin Creek at Islip 2 & - & - & - & - & - & - & - & - & - & - & - & - \\
\hline 01307500 - Penataquit Creek at Bay Shore & 6.16 & 5.56 & 6.51 & 7.50 & 6.89 & 7.22 & 6.87 & 5.26 & 5.47 & 4.10 & 2.92 & 3.27 \\
\hline 01308000 - Sampawams Creek at Babylon 3 & 4.10 & 5.77 & 8.70 & 11.34 & 10.89 & 11.18 & 15.12 & 10.07 & 7.21 & 4.76 & 3.47 & 5.30 \\
\hline 01308500 - Car11s River at Babylon & 14.98 & 17.25 & 25.06 & 30.74 & 25.79 & 29.00 & 32.20 & 24.06 & 18.98 & 13.87 & 11.35 & 17.77 \\
\hline 01309000 - Santapogue Creek at Lindenhurst2 & - & - & - & - & - & - & - & - & - & - & - & - \\
\hline 01309500 - Massapequa Creek at Massapequa & 4.18 & 3.86 & 7.35 & 9.03 & 8.96 & 9.74 & 12.50 & 9.04 & 6.52 & 3.93 & 3.59 & 4.90 \\
\hline 01310000 - Bellmore Creek at Bellmore 4 & 4.97 & 5.59 & 7.78 & 11.99 & 10.90 & 11.03 & 12.97 & 10.38 & 9.21 & 3.41 & 4.62 & 4.25 \\
\hline 01310500 - East Meadow Brook at Freeport & 3.34 & 3.55 & 6.34 & 9.71 & 11.60 & 9.29 & 9.17 & 6.51 & 4.02 & 1.67 & 1.01 & 2.56 \\
\hline 01311000 - Pines Brook at Malverne & .12 & .192 & .51 & .62 & .55 & .58 & .86 & .51 & .28 & .05 & 0 & .007 \\
\hline 01311500 - Valley Stream at Valley Stream & 0 & 0 & 0 & 0 & 0 & .007 & .163 & .04 & 0 & 0 & 0 & 0 \\
\hline
\end{tabular}

* Monthly mean base flow calculated from wholly or partially estimated records.

1 Including diversion through hatchery.

2 Champlin Creek and Santapogue Creek discontinued as continuous gaging stations.

3 Indeterminate effect on base flow caused by ground-water pumpage at well field one-quarter mile northwest of gage.

4 Base flow at auxiliary gage augmented to unknown degree by dewatering, associated with sewer construction, from

May through September 1974. 
Water Year 1975

\begin{tabular}{|c|c|c|c|c|c|c|c|c|c|c|c|c|}
\hline Station & Oct. & Nov。 & Dec. & Jan. & Feb。 & Mar. & Apr。 & May & June & July & Aug. & sept. \\
\hline 01302500 - Glen Cove Creek at Glen Cove & 3.46 & 3.66 & 5.10 & 5.55 & 5.05 & 4.66 & 4.48 & 4.47 & 5.05 & 5.25 & 4.89 & 5.96 \\
\hline 01303000 - Mi11 Neck Creek at Mil1 Neck & 7.61 & 7.62 & 8.37 & 9.12 & 9.05 & 8.51 & 8.23 & 8.30 & 8.08 & 8.80 & 8.35 & 8.85 \\
\hline 01303500 - Cold Spring Brook at Cold Spring Harborl & 4.10 & 4.51 & 4.77 & 5.11 & 5.28 & 4.57 & 4.25 & 4.82 & 5.31 & 4.75 & 4.08 & 3.96 \\
\hline 01304000 - Nissequogue River near Smithtown & 35.06 & 36.27 & 41.65 & 45.23 & 45.25 & 45.71 & 44.57 & 43.74 & 43.40 & $41.03 *$ & $41.19 *$ & 40.00 \\
\hline 01304500 - Peconic River at Riverhead & 25.79 & 24.20 & 36.58 & 49.77 & 49.68 & 51.52 & 51.30 & 54.77 & 52.63 & 37.26 & 26.52 & 25.13 \\
\hline 01305000 - Carmans River at Yaphank & 21.34 & 20.80 & 22.73 & 24.68 & 26.05 & 26.48 & 27.73 & 26.82 & 26.83 & 25.61 & 23.45 & 22.95 \\
\hline 01305500 - Swan River at East Patchogue & 9.57 & 9.37 & 10.68 & 11.61 & 12.70 & 13.65 & 13.22 & 14.79 & 14.22 & 13.19 & 11.25 & 9.82 \\
\hline 01306000 - Patchogue River at Patchogue & 15.19 & 15.12 & 18.00 & 19.68 & 20.95 & 20.82 & 21.05 & 20.35 & 20.60 & 20.40 & 18.90 & 18.03 \\
\hline 01306500 - Connetquot River near Oakdale2 & $30.00 *$ & $28.10^{*}$ & $39.90 *$ & $41.70 *$ & $42.10 *$ & $44.60 *$ & $45.10 *$ & $45.00 *$ & $46.50^{*}$ & $40.20 *$ & $33.60 *$ & $34.40^{*}$ \\
\hline 01307000 - Champlin Creek at Islip 3 & - & - & - & - & - & - & - & - & - & - & - & - \\
\hline 01307500 - Penataquit Creek at Bay Shore & 3.52 & 3.50 & 5.43 & 6.61 & 6.89 & 7.77 & 9.92 & 7.69 & 7.51 & 6.25 & 5.02 & 4.16 \\
\hline 01308000 - Sampawams Creek at Baby $10 n^{4}$ & 5.90 & 9.59 & 12.66 & 12.81 & 13.98 & 15.00 & 16.12 & 14.30 & 16.75 & 20.73 & 10.79 & 11.43 \\
\hline 01308500 - Car11s River at Babylon & 15.45 & 14.72 & 21.94 & 25.16 & 27.23 & 28.27 & 30.05 & 32.77 & 34.50 & 28.13 & $19.84 *$ & $14.53 *$ \\
\hline 01309000 - Santapogue Creek at Lindenhurst 3 & - & - & - & - & - & - & - & - & - & - & - & - \\
\hline 01309500 - Massapequa Creek at Massapequa & 4.46 & 3.98 & 6.75 & 8.99 & 10.45 & 12.58 & 12.20 & 9.04 & $16.37 *$ & 12.07 & 9.45 & 8.38 \\
\hline 01310000 - Bellmore Creek at Bellmore 5 & 7.87 & 7.43 & 7.33 & 8.32 & 8.60 & 10.43 & 10.50 & 10.72 & 14.22 & 16.22 & 17.13 & 8.62 \\
\hline 01310500 - East Meadow Brook at Freeport & 2.60 & 2.41 & 4.15 & 6.36 & 7.74 & 8.94 & 9.21 & 9.77 & 14.83 & 13.58 & 9.72 & 9.62 \\
\hline 01311000 - Pines Brook at Malverne & 0 & 0 & .149 & .47 & .45 & .60 & .63 & .53 & .62 & $.47 *$ & .22 & $.30 *$ \\
\hline 01311500 - Valley Stream at Valley Stream & 0 & 0 & 0 & 0 & 0 & 0 & 0 & .042 & .132 & .299 & .117 & .152 \\
\hline
\end{tabular}

* Monthly mean base flow calculated from wholly or partially estimated records.

1 Including diversion through hatchery.

2 No discharge record for base gage, October 1974 through September 1975. MonthIy mean base flow taken as a percentage of estimated monthly mean discharge.

3 Champlin Creek and Santapogue Creek discontinued as continuous gaging stations.

4 Indeterminate effect on base flow caused by ground-water pumpage at well field one-quarter mile northwest of gage.

5 Base flow at auxiliary gage augmented to unknown degree by dewatering, associated with sewer construction, from

October 1974 through January 1975. 